Check for updates

Cite this: RSC Adv., 2018, 8, 17511

Received 8th March 2018

Accepted 30th April 2018

DOI: $10.1039 / \mathrm{c} 8 \mathrm{ra02078g}$

rsc.li/rsc-advances

\section{Synthesis and biological evaluation of 2-aryl- benzimidazole derivatives of dehydroabietic acid as novel tubulin polymerization inhibitors $\uparrow$}

\author{
Ting-Ting Miao, \$ Xu-Bing Tao, \$ Dong-Dong Li, Hao Chen, Xiao-Yan Jin, Yi Geng, \\ Shi-Fa Wang (D) and Wen Gu (D)*
}

A series of novel 2-aryl-benzimidazole derivatives of dehydroabietic acid were synthesized and characterized by IR, ${ }^{1} \mathrm{H}$ NMR, ${ }^{13} \mathrm{C}$ NMR, MS and elemental analyses. All the target compounds were evaluated for their in vitro cytotoxic activity against SMMC-7721, MDA-MB-231, HeLa and CT-26 cancer cell lines and the normal hepatocyte cell line QSG-7701 through MTT assays. Among them, compound 6j displayed the most potent cytotoxic activity with $I_{50}$ values of $0.08 \pm 0.01,0.19 \pm 0.04,0.23 \pm 0.05$ and $0.42 \pm 0.07 \mu \mathrm{M}$, respectively, and substantially reduced cytotoxicity against QSG-7701 cells (5.82 \pm $0.38 \mu \mathrm{M})$. The treatment of SMMC-7721 cells with compound $6 \mathrm{j}$ led to considerable inhibition of cell migration ability. The influence of compound $6 \mathbf{j}$ on cell cycle distribution was assessed on SMMC-7721 cells, exhibiting a cell cycle arrest at the G2/M phase. Moreover, tubulin polymerization assays and immunofluorescence assays elucidated that compound $6 \mathrm{j}$ could significantly inhibit tubulin polymerization and disrupt the intracellular microtubule network. A molecular docking study provided insight into the binding mode of compound $6 \mathrm{j}$ in the colchicine site of tubulin. In addition, compound $6 \mathrm{j}$ was found to induce apoptosis of SMMC-7721 cells, an increase of intracellular ROS level and a loss of mitochondrial membrane potential in a dose-dependent manner. These findings provided new molecular scaffolds for the further development of novel antitumor agents targeting tubulin polymerization.

\section{Introduction}

Microtubules, as key components of the cytoskeleton, are dynamic polymers of $\alpha$, $\beta$-tubulin and involved in a series of important cellular processes including regulation of motility, cell signaling, maintenance of cell shape, cell proliferation and intracellular transport. ${ }^{1-4}$ Due to the multiple functions of microtubules in the cell cycle, tubulin has become an attractive target for the development of novel antimitotic agents for cancer therapy. ${ }^{5,6}$ Antimitotic agents are generally divided into two types: microtubule stabilizing agents (e.g., paclitaxel, epothilones) and tubulin polymerization inhibitors (e.g., vinca alkaloids, colchicine). Three major binding sites on microtubules have been identified as the taxane-, vinca alkaloid- and colchicine-binding sites. ${ }^{7}$ Disruption of microtubule dynamics by these compounds will lead to cell cycle arrest at G2/M phase and induction of apoptosis. ${ }^{8}$

\footnotetext{
Jiangsu Provincial Key Lab for the Chemistry and Utilization of Agro-forest Biomass, Jiangsu Key Lab of Biomass-based Green Fuels and Chemicals, College of Chemical Engineering, Nanjing Forestry University, Nanjing 210037, P. R. China. E-mail: njguwen@163.com

$\dagger$ Electronic supplementary information (ESI) available. See DOI: $10.1039 / \mathrm{c} 8 \mathrm{ra02078g}$

¥ These two authors contributed equally to this study.
}

In the past several decades, antimitotic agents interacting with the taxane- or vinca alkaloid-binding sites have acquired tremendous success in clinical oncology. However, compounds targeting the colchicine-binding site have drawn increasing interest from medicinal chemists in recent years for their high anticancer potency, selective toxicity toward tumor vasculature and promising ability to overcome P-glycoprotein (P-gp) efflux pump mediated multidrug resistance. ${ }^{9-11}$ For example, combretastatin A-4 (CA-4) (Fig. 1) is a natural (Z)-stilbene isolated from the South African bush willow tree Combretum caffrum by Pettit and co-workers in $1989 .{ }^{12}$ Through binding to the colchicine site, CA-4 can significantly inhibit tubulin polymerization and exhibit a potent cytotoxicity at nanomolar level against a wide range of human cancer cells. Moreover, CA-4 displayed a selective toxicity towards the vascular network of tumors, inducing an irreversible shutdown of blood flow to neoplastic cells. ${ }^{13}$ Some water soluble prodrugs of CA-4 were subjected to clinical trials, ${ }^{14}$ among which the phosphate disodium prodrug (CA-4P, fosbretabulin, Zybrestat ${ }^{\mathrm{TM}}$ ) received the orphan drug status (USA and Europe) in 2016 to treat neuroendocrine tumors (NETs) and glioblastoma multiform (GBM) ${ }^{15,16}$ Therefore, antimitotic agents targeting the colchicine-binding site have proved to be a promising source for the development of novel and potent anticancer drugs. 
<smiles>COc1cc2c(c(OC)c1OC)-c1ccc(OC)c(=O)cc1[C@@H](NC(C)=O)CC2</smiles>

Colchicine<smiles>[R]Oc1cc(/C=C\c2cc(OC)c(OC)c(OC)c2)ccc1OC</smiles>

CA-4P R $=\mathrm{OPO}_{3} \mathrm{Na}_{2}$<smiles>COC(=O)Nc1nc2cc(Sc3ccc(NC(=O)C(C)N)cc3)ccc2[nH]1</smiles>

Denibulin<smiles>COC(=O)Nc1nc2cc(C(=O)c3cccs3)ccc2[nH]1</smiles>

Nocodazole

CXI-benzo-84

NSC:761109/1<smiles>COC(=O)C1(C)CCCC2(C)c3cc(Br)c4nc(C#N)[nH]c4c3CCC12C</smiles>

6a-k<smiles>COC(=O)[C@]1(C)CCCC2(C)c3cc(-c4cc(OC)c(OC)c(OC)c4)c4nc(C#N)[nH]c4c3CCC21</smiles>

7a-k

Fig. 1 Structures of some reported antimitotic agents targeting colchicine-binding site and the newly synthesized 2-aryl-benzimidazole derivatives of dehydroabietic acid $(6 a-k$ and $7 a-k)$.

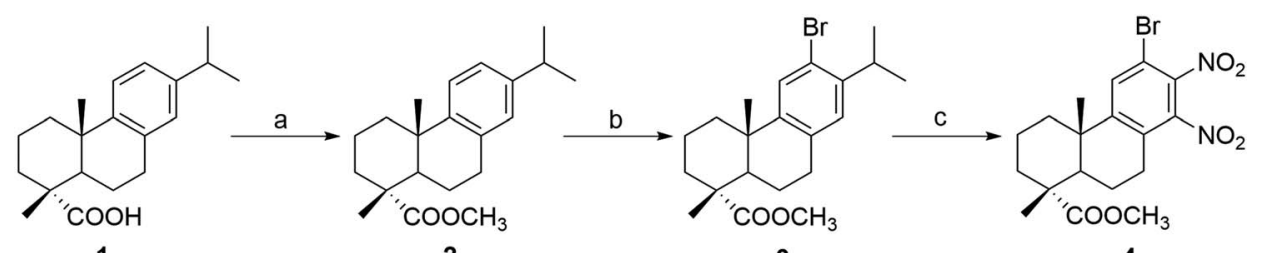

1

2

3<smiles>COc1cccc(OC)c1OC</smiles><smiles>COC(=O)[C@]1(C)C[C@H](C)[C@H]2CCc3cc(Br)c(N)c(N)c3[C@]2(C)C1</smiles>

5<smiles>CC[C@]1(C)c2cc(Br)c3nc([Al])[nH]c3c2CCC1C(=O)OC</smiles>

6

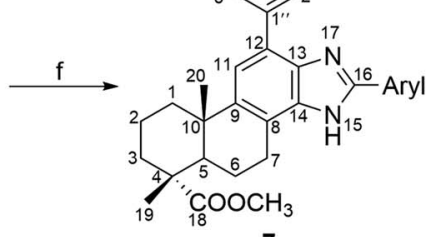

7<smiles>COc1ccc(C)cc1</smiles><smiles>Cc1cccc(F)c1</smiles><smiles>Cc1ccccc1F</smiles><smiles>Cc1ccc(Cl)cc1</smiles>

d

e<smiles></smiles><smiles>Cc1c[nH]c2ccccc12</smiles>

k

Scheme 1 Reagents and conditions: (a) (i) $\mathrm{SOCl}_{2}$, benzene, reflux, $3 \mathrm{~h}$, (ii) $\mathrm{MeOH}$, reflux, $5 \mathrm{~h}$; (b) NBS, $\mathrm{MeCN}$ rt, 24 h; (c) fuming HNO 3 , $\mathrm{H}_{2} \mathrm{SO}_{4}$, $0{ }^{\circ} \mathrm{C}, 40 \mathrm{~min}$; (d) $\mathrm{Fe}, \mathrm{EtOH}, \mathrm{H}_{2} \mathrm{O}, \mathrm{HCl}$, reflux, $4 \mathrm{~h}$; (e) substituted arylaldehyde, p-toluenesulfonic acid, EtOH, $85^{\circ} \mathrm{C}, 24 \mathrm{~h}$; (f) $3,4,5$-trimethoxyphenylboronic acid, $\mathrm{Pd}\left(\mathrm{PPh}_{3}\right)_{4}, \mathrm{~K}_{2} \mathrm{CO}_{3}, \mathrm{THF}, \mathrm{H}_{2} \mathrm{O}, 85^{\circ} \mathrm{C}, 24 \mathrm{~h}$. 
Table 1 The in vitro cytotoxic activities of the tested compounds (1-5, 6a-k and 7a-k) against four cancer cell lines (SMMC-7721, MDA-MB-231, HeLa and CT-26) and one normal hepatocyte cell line (QSG-7701)

\begin{tabular}{|c|c|c|c|c|c|}
\hline \multirow[b]{2}{*}{ Compound } & \multicolumn{5}{|l|}{$\mathrm{IC}_{50}(\mu \mathrm{M})$} \\
\hline & SMMC-7721 & MDA-MB-231 & HeLa & CT-26 & QSG-7701 \\
\hline 2 & $>50$ & $>50$ & $>50$ & $>50$ & NT \\
\hline 3 & $>50$ & $>50$ & $>50$ & $>50$ & NT \\
\hline 4 & $31.80 \pm 3.22$ & $38.76 \pm 2.15$ & $>50$ & $35.13 \pm 3.87$ & NT \\
\hline $6 b$ & $>50$ & $>50$ & $>50$ & $25.26 \pm 4.96$ & NT \\
\hline $6 c$ & $1.52 \pm 0.77$ & $18.21 \pm 1.20$ & $8.01 \pm 0.76$ & $2.82 \pm 0.97$ & $>50$ \\
\hline 6d & $5.27 \pm 0.27$ & $11.97 \pm 1.31$ & $17.73 \pm 3.02$ & $3.39 \pm 0.33$ & $>50$ \\
\hline $6 e$ & $12.28 \pm 2.46$ & $>50$ & $>50$ & $>50$ & NT \\
\hline $6 f$ & $16.49 \pm 1.87$ & $33.66 \pm 4.70$ & $>50$ & $>50$ & NT \\
\hline $6 \mathrm{~g}$ & $40.81 \pm 3.32$ & $19.21 \pm 0.93$ & $>50$ & $>50$ & NT \\
\hline $7 a$ & $9.38 \pm 1.02$ & $>50$ & $13.12 \pm 1.70$ & $8.25 \pm 0.50$ & $>50$ \\
\hline $7 \mathbf{b}$ & $>50$ & $>50$ & $>50$ & $15.60 \pm 1.57$ & NT \\
\hline $7 c$ & $3.29 \pm 0.13$ & $0.69 \pm 0.21$ & $7.63 \pm 1.03$ & $8.95 \pm 0.17$ & $36.07 \pm 2.32$ \\
\hline $7 d$ & $>50$ & $6.42 \pm 0.04$ & $12.89 \pm 1.26$ & $2.70 \pm 0.12$ & $>50$ \\
\hline $7 e$ & $>50$ & $18.20 \pm 1.32$ & $18.34 \pm 2.98$ & $10.41 \pm 1.91$ & NT \\
\hline $7 f$ & $11.00 \pm 2.68$ & $10.14 \pm 1.38$ & $17.21 \pm 2.32$ & $3.44 \pm 0.75$ & $>50$ \\
\hline $7 g$ & $>50$ & $15.74 \pm 0.87$ & $>50$ & $13.43 \pm 2.35$ & NT \\
\hline $7 \mathbf{h}$ & $>50$ & $8.84 \pm 1.08$ & $29.88 \pm 3.07$ & $2.76 \pm 0.26$ & $>50$ \\
\hline $7 \mathbf{i}$ & $>50$ & $>50$ & $>50$ & $23.52 \pm 2.38$ & NT \\
\hline $7 \mathbf{j}$ & $2.35 \pm 1.09$ & $0.83 \pm 0.20$ & $3.75 \pm 0.78$ & $0.59 \pm 0.08$ & $12.83 \pm 1.27$ \\
\hline $7 \mathbf{k}$ & $1.95 \pm 0.56$ & $0.21 \pm 0.02$ & $5.86 \pm 0.63$ & $0.45 \pm 0.03$ & $11.78 \pm 2.12$ \\
\hline Nocodazole & $0.92 \pm 0.07$ & $0.76 \pm 0.06$ & $0.87 \pm 0.05$ & $1.37 \pm 0.11$ & $13.75 \pm 1.08$ \\
\hline
\end{tabular}

Nitrogen-containing heterocycles play a vital role in the field of medicinal chemistry because they can easily interact with biomolecules of living systems. ${ }^{17}$ Among them, benzimidazole has been considered as a prominent heterocyclic scaffold found in many natural and synthetic drugs which exhibit a wide range of therapeutic properties..$^{18}$ As antitumor agents, benzimidazole derivatives can exert their antitumor activity by acting on various targets such as topoisomerase inhibitors, DNA intercalating agents, androgen receptor antagonists, antiangiogenic agents, poly(ADP-ribose) polymerase (PARP) inhibitors, dihydrofolate reductase inhibitors, protein tyrosine kinase inhibitors and tubulin polymerization inhibitors. ${ }^{19-25}$ For example, nocodazole (NSC-238189), with benzimidazole as its basic scaffold, is a well-known anticancer agent that significantly inhibits the polymerization of tubulin at nanomolar concentration. ${ }^{26}$ Besides nocodazole, a number of benzimidazole derivatives such as denibulin, ${ }^{27} \mathrm{CXI}$-benzo-84, ${ }^{28} \mathrm{NSC}: 761109 / 1,{ }^{29}$ etc. have also been reported as potent tubulin polymerization inhibitors binding to the colchicine site (Fig. 1). On the other hand, some above-mentioned compounds such as colchicine and CA-4 shared a common 3,4,5-trimethoxyphenyl (TMP) moiety in their chemical structures, implying this moiety might be crucial for their anti-tubulin polymerization activities. ${ }^{30}$
These findings suggested that benzimidazole and TMP moieties could be useful pharmacophores for the design of novel tubulin polymerization inhibitors.

Natural products provide a rich source for new medicinal leads and play a major role in drug discovery, especially in the area of cancer therapy. ${ }^{31}$ Dehydroabietic acid (DAA, 1) is a natural diterpenic resin acid which can be easily isolated from Pinus rosin or commercial disproportionated rosin. DAA and its derivatives has been found to exhibit a broad spectrum of biological activities, such as antimicrobial, antiprotozoal, antiviral, antiulcer, anti-aging and radical scavenging activities. ${ }^{32-37}$ Especially, a lot of DAA derivatives have been reported exhibiting prominent anticancer activity through various mechanisms including DNA binding, ${ }^{38}$ induction of apoptosis ${ }^{39}$ or oncosis ${ }^{40}$ and inhibition of cancer cell migration. ${ }^{11}$ These results suggest that dehydroabietic acid is a promising lead compound for the investigation of new anticancer agents, and the incorporation of benzimidazole and TMP moieties to the structure of DAA may result in novel hybrid molecules with improved antimitotic properties. In continuation of our research on novel bioactive derivatives of DAA, ${ }^{42,43}$ a series of new 2-aryl-benzimidazole derivatives of DAA were designed and synthesized, which were assayed for their in vitro antiproliferative activity against several 
cell lines. In addition, the possible anticancer mechanisms of these derivatives as tubulin polymerization inhibitor and apoptosis inducer were also preliminarily explored.

\section{Results and discussion}

\section{Chemistry}

The target compounds (6a-k and 7a-k) were synthesized according to the method outlined in Scheme 1. The key intermediate methyl 12-bromo-13,14-dinitro-deisopropyldehydroabietate (4) was synthesized from dehydroabietic acid based on the procedure reported in a previous literature. ${ }^{44}$ Subsequently, two nitro groups of compound $\mathbf{4}$ were reduced by Fe powder to afford the diamino derivatives 5 in 57\% yield, which was then reacted with different substituted arylaldehyde to get a series of 2 -aryl-12-bromobenzimidazole derivatives (6a-k) in 60-83\% yield. Furthermore, compounds $\mathbf{6 a - k}$ were reacted with 3,4,5-trimethoxyphenylboronic acid in the presence of $\mathrm{Pd}\left(\mathrm{PPh}_{3}\right)_{4}$ and $\mathrm{K}_{2} \mathrm{CO}_{3}$ to afford the corresponding $2^{\prime}$-aryl-12-(3,4,5-trimethoxyphenyl)benzimidazole derivatives $(\mathbf{7 a - k})$ in $50-73 \%$ yield. All the synthesized compounds were purified by recrystallization or silica gel column chromatography.

The structures of compounds $6 \mathbf{a}-\mathbf{k}$ and $7 \mathbf{a}-\mathbf{k}$ were characterized on the basis of MS, IR, ${ }^{1} \mathrm{H}$ NMR, ${ }^{13} \mathrm{C}$ NMR and elemental analyses. In a typical example, the ESIMS of compound $\mathbf{6 j}$ displayed two peaks at $m / z 506$ and 508, corresponding to the quasimolcular ions $[\mathrm{M}+\mathrm{H}]^{+}$, whcih also suggested the presence of a bromine atom. The data of molecular weight in combination with the elemental analysis confirmed the molecular formula of compound $6 \mathbf{j}$ as $\mathrm{C}_{27} \mathrm{H}_{28} \mathrm{BrN}_{3} \mathrm{O}_{2}$. The IR spectrum of 6j exhibited a broad strong peaks at $3325 \mathrm{~cm}^{-1}$ corresponding to the $\mathrm{N}-\mathrm{H}$ stretch vibrations and two strong $\mathrm{C}-\mathrm{H}$ vibration bands at 2929 and $2866 \mathrm{~cm}^{-1}$ attributed to the $\mathrm{C}-\mathrm{H}$ stretch vibrations. In addition, a very strong absorption band at $1703 \mathrm{~cm}^{-1}$ was due to the $\mathrm{C}=\mathrm{O}$ stretch vibrations of the methyl ester moiety. The ${ }^{1} \mathrm{H}$-NMR spectrum of $\mathbf{6 j}$ showed three singlets at $\delta 1.28,1.32$ and $3.69 \mathrm{ppm}$, attributed to methyl protons at C$19, \mathrm{C}-20$ and 18-ester group, respectively. The peaks in the range of $\delta$ 1.50-3.20 ppm could be attributed to the eleven protons of five aliphatic methylenes and an aliphatic methine at C-5. The six peaks appeared at $\delta 6.62,7.28,7.32,7.45,7.90$ and $8.29 \mathrm{ppm}$ could be assigned as the aromatic protons in the benzimidazole and indole moieties, and the $\mathrm{N}-\mathrm{H}$ signals appeared as a broad single peak at $\delta 8.44 \mathrm{ppm}$. In the ${ }^{13} \mathrm{C}-\mathrm{NMR}$ spectrum of $\mathbf{6 j}$, there were 27 peaks appearing in the range from $\delta 16-180 \mathrm{ppm}$. Among them, fifteen peaks at $\delta$ 100-155 ppm, including six tertiary carbons and nine quaternary carbons, were due to the aromatic carbons on the benzimidazole and indole moieties. In addition, The peaks at $\delta 52.2$ and $179.5 \mathrm{ppm}$ could be attributed to the signals of methyl carbon and carbonyl carbon on C-18
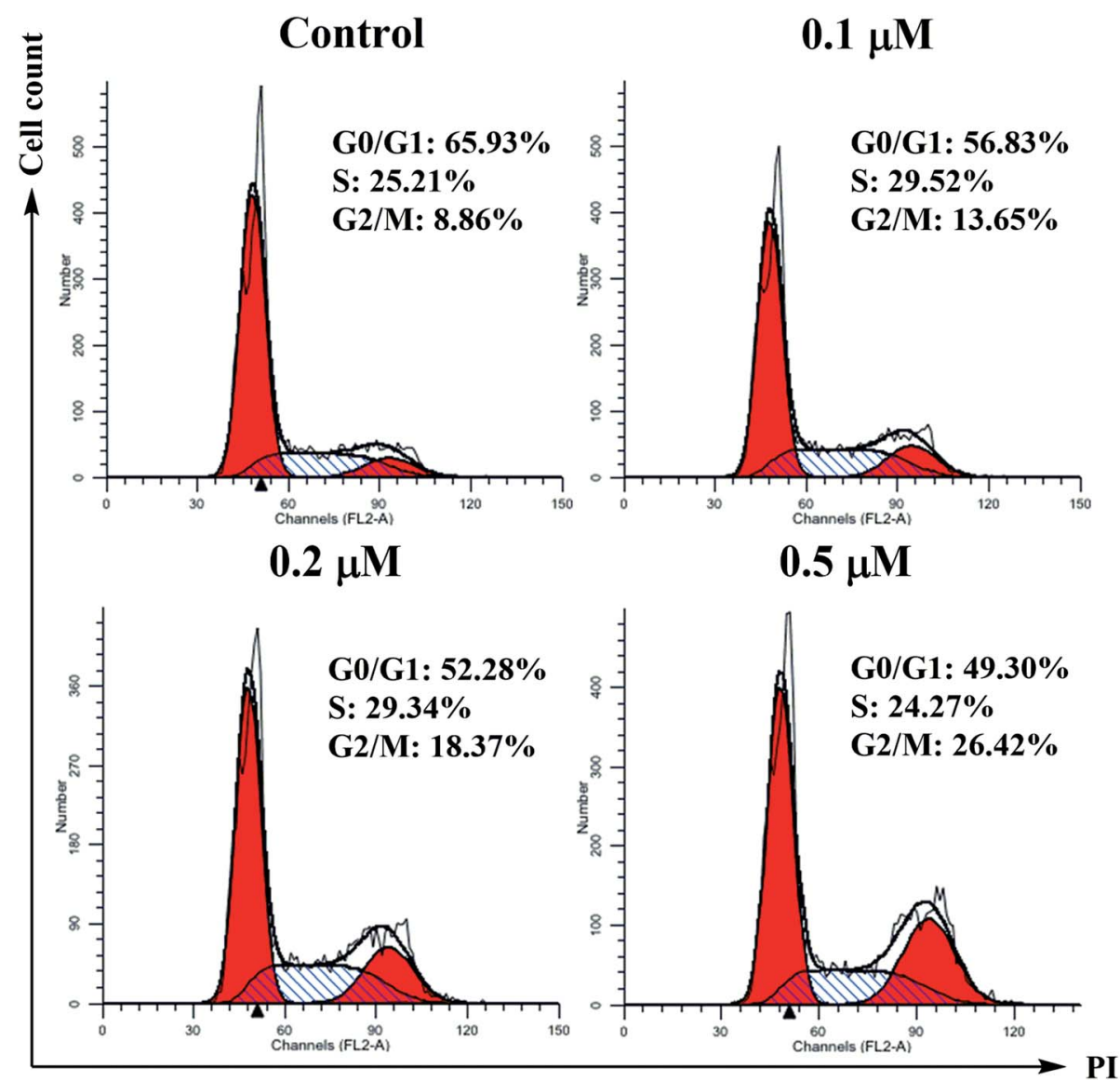

Fig. 2 Effects of compound 6j on cell cycle progression of SMMC-7721 cells. The analysis of cell cycle distribution was performed by using propidium iodide staining method. Cells were treated with $0.1,0.2$ and $0.5 \mu \mathrm{M}$ of $6 \mathrm{j}$ for $24 \mathrm{~h}$. 


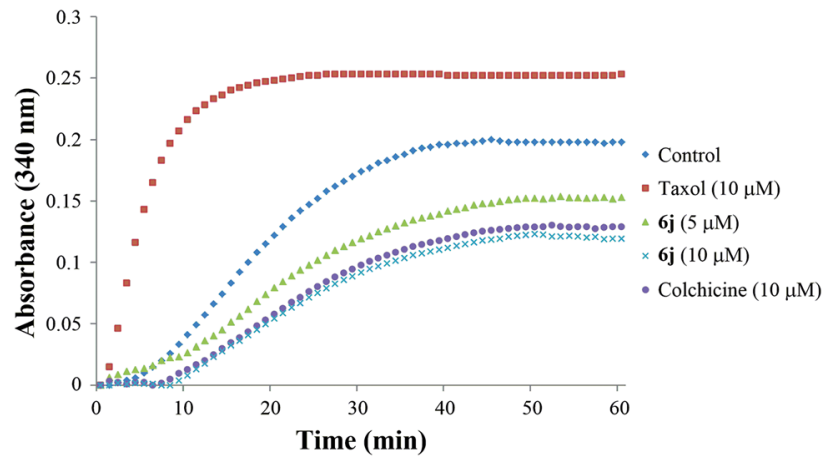

Fig. 3 Effect of compound $6 \mathrm{j}$ on tubulin polymerization. Colchicine $(10 \mu \mathrm{M})$ and taxol $(10 \mu \mathrm{M})$ was used as the positive control (purple) and negative control (red), respectively, and G-PEM buffer was used as the blank control (blue). Tubulin was also treated with compound $6 \mathrm{j}$ at 5 $\mu \mathrm{M}$ (yellow) and $10 \mu \mathrm{M}$ (green) concentrations. The reaction was monitored at OD $340 \mathrm{~nm}$ at $37^{\circ} \mathrm{C}$ for $1 \mathrm{~h}$.

ester group, respectively. The assignments of the signals in the ${ }^{1} \mathrm{H}$ and ${ }^{13} \mathrm{C}$ NMR spectra of compound $\mathbf{6 j}$ were in good accordance with its structure. As for compound $7 \mathbf{j}$, its ESIMS spectrum and elemental analysis data also confirmed its molecular formula $\mathrm{C}_{36} \mathrm{H}_{39} \mathrm{~N}_{2} \mathrm{O}_{5}$. The ${ }^{1} \mathrm{H}$ NMR spectrum of $7 \mathbf{j}$ exhibited two singlets at $\delta 3.93\left(\mathrm{OCH}_{3}\right)$ and $3.96 \mathrm{ppm}\left(\mathrm{OCH}_{3} \times 2\right)$ and a $2 \mathrm{H}$ singlet at $\delta 6.82 \mathrm{ppm}\left(\mathrm{H}-2^{\prime \prime}\right.$ and $\left.\mathrm{H}-6^{\prime \prime}\right)$. The ${ }^{13} \mathrm{C}$ NMR spectra of $7 \mathbf{j}$ also demonstrated six additional peaks compared with compound 6j. Among them, the peaks at $\delta 56.5$ and $61.1 \mathrm{ppm}$ were attributed to the three methoxyl groups in the benzene

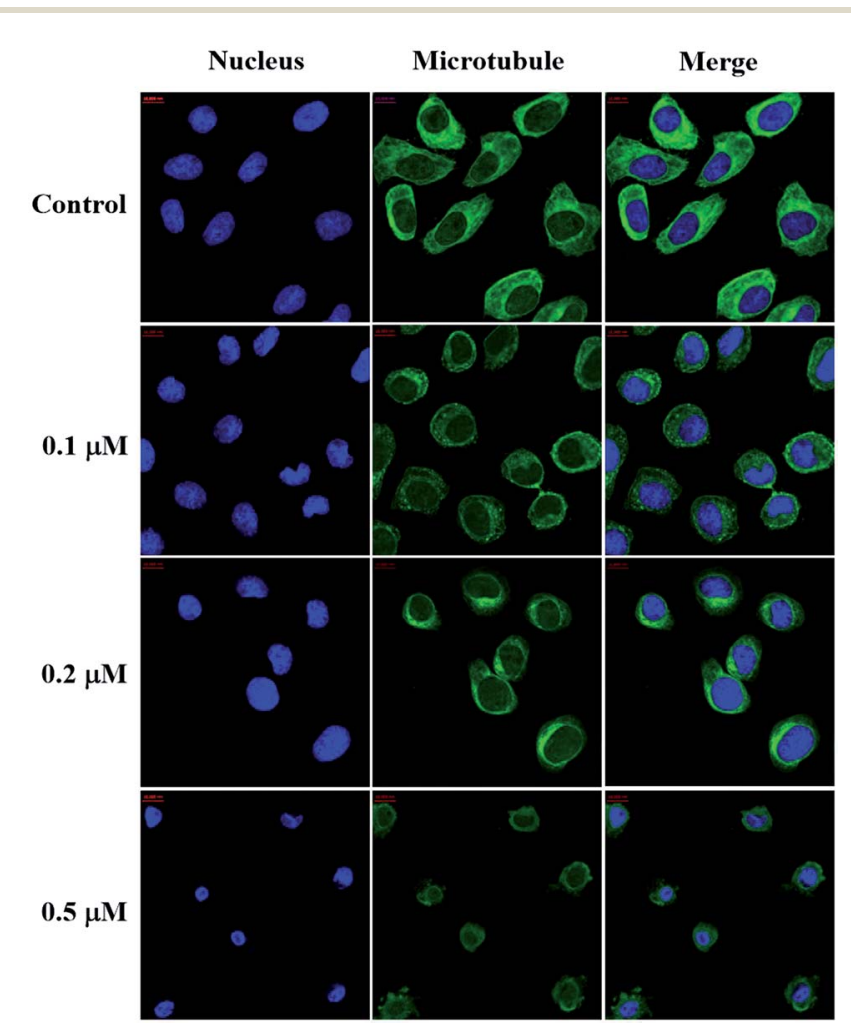

Fig. 4 Effect of compound $6 \mathrm{j}$ on the microtubule network of SMMC7721 cells. SMMC -7721 cells were untreated (control) and treated with compound $6 \mathrm{j}$ at $0.1,0.2$ and $0.5 \mu \mathrm{M}$ for $24 \mathrm{~h}$. Microtubules and unassembled tubulin were shown in green and the nuclei were in blue. ring. These signals clearly indicated the presence of 3,4,5-trimethoxyphenyl moiety in compound $\mathbf{7 j}$.

\section{Biological evaluation}

In vitro antiproliferative activity. The in vitro antiproliferative activity of DAA derivatives (1-5, $\mathbf{6 a - k}, \mathbf{7 a - k})$ were evaluated by MTT assay against human hepatocarcinoma cell line (SMMC7721), human breast cancer cell line (MDA-MB-231), human cervical carcinoma cell line (HeLa), mouse colon cancer cell line (CT-26) and human normal hepatocyte cell line (QSG-7701). Nocodazole was co-assayed as the positive control and DMEM culture medium containing $0.1 \%$ DMSO was used as negative control. The results of the tested compounds expressed as $\mathrm{IC}_{50}$ values (concentration required to inhibit tumor cell proliferation by $50 \%$ ) were presented in Table 1 .

From the results, the target compounds exhibited varying degrees of cytotoxic activity against four cancer cell lines. Specifically, compounds $\mathbf{6 c}, \mathbf{6 d}, \mathbf{6 j}, \mathbf{6 k}, 7 \mathbf{c}, 7 \mathbf{j}$ and $7 \mathbf{k}$ showed significant anticancer activity against SMMC-7721 cells with $\mathrm{IC}_{50}$ values below $5 \mu \mathrm{M}$, compounds $\mathbf{6 j}, \mathbf{6 k}, 7 \mathbf{c}, 7 \mathbf{j}$ and $7 \mathbf{k}$ displayed strong cytotoxicity against MDA-MB-231 cells, compounds $\mathbf{6 j}, \mathbf{6 k}, 7 \mathbf{j}$ and $7 \mathbf{k}$ showed strong inhibition against HeLa cells, and compounds $\mathbf{6 c}, \mathbf{6 d}, \mathbf{6 j}, \mathbf{6 k}, \mathbf{7 d}, \mathbf{7 f}, 7 \mathbf{h}, 7 \mathbf{j}$ and $7 \mathbf{k}$ exhibited pronounced activity against CT-26 cells $\left(\mathrm{IC}_{50}<5 \mu \mathrm{M}\right)$. In general, compounds $\mathbf{6 a - k}$ exhibited stronger activity against SMMC-7721 cells than the other three cancer cell lines, while compounds $7 \mathbf{a}-\mathbf{k}$ were most cytotoxic to CT-26 cells. Among these derivatives, compound $\mathbf{6 j}$ exhibited the most potent anticancer activity against all the four cancer cell lines, with $\mathrm{IC}_{50}$ values of $0.08 \pm 0.01,0.19 \pm 0.04,0.23 \pm 0.05$ and $0.42 \pm 0.07$ $\mu \mathrm{M}$, respectively, stronger than the positive control nocodazole. In addition, compounds $\mathbf{6 k}, 7 \mathbf{j}$ and $7 \mathbf{k}$ also exhibited potent cytotoxic activity at low $\mu \mathrm{M}$ range. It is worth noting that compounds $\mathbf{6 j}, \mathbf{6 k}$ and $\mathbf{7 j}, \mathbf{7 k}$ were significantly less cytotoxic to human normal hepatocyte cell line QSG-7701, which indicated that these compounds possessed potent and selective antiproliferative activity on the tested cancer cell lines.

Based on the above observation, some interesting structureactivity relationships (SAR) could be concluded. As shown in Table 1, the cytotoxic activities of most target derivatives (6a-k, $\mathbf{7 a - k )}$ with benzimidazole moieties were superior to DAA (1) and intermediates 2-5, which indicated that the introduction of benzimidazole moiety could significantly improve the cytotoxicity. However, compounds $7 \mathbf{a}-\mathbf{k}$ did not exhibit much stronger cytotoxic activities than compounds $\mathbf{6 a - k}$, suggesting that the displacement of 12-Br with 12-(3,4,5-trimethoxyphenyl) moiety were not obviously advantageous to anticancer activity as expected. On the other hand, the 2 -aryl groups on benzimidazole rings also significantly affected the cytotoxic potencies of the target compounds. For series $\mathbf{6 a - k}$, compounds $\mathbf{6 c}, \mathbf{6 f}, \mathbf{6 h}$ with $p$ fluoro, $p$-chloro and $p$-bromo substituents on the benzene rings exhibited substantially stronger cytotoxic activity than compounds $\mathbf{6 b}$ and $\mathbf{6 i}$ with $p$-methyl and $p$-methoxy groups. In addition, compound $\mathbf{6 c}$ with $p$-fluoro group was more cytotoxic than 6d with $m$-fluoro group which was also more cytotoxic than 6e with $o$-fluoro group. The similar results could also be 


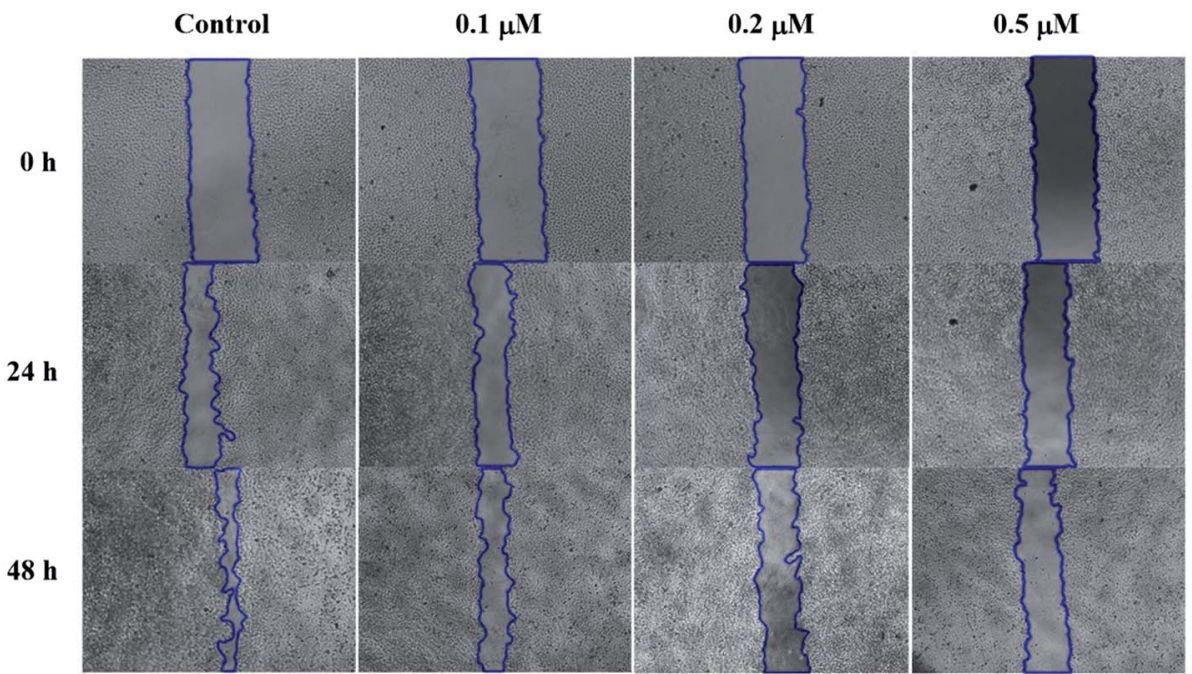

Fig. 5 Effect of compound $6 \mathrm{j}$ on in vitro migration potential of SMMC-7721 cells. Scratches were created with sterile $200 \mu \mathrm{L}$ pipette and images were captured using phase contrast microscopy at 0,24 and $48 \mathrm{~h}$ after treatment with $0,0.1,0.2$ and $0.5 \mu \mathrm{M}$ of compound $6 \mathrm{j}$.

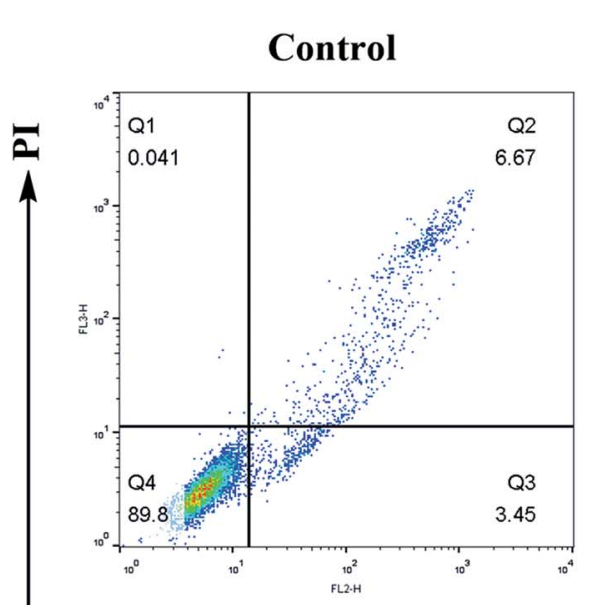

$0.5 \mu \mathrm{M}$

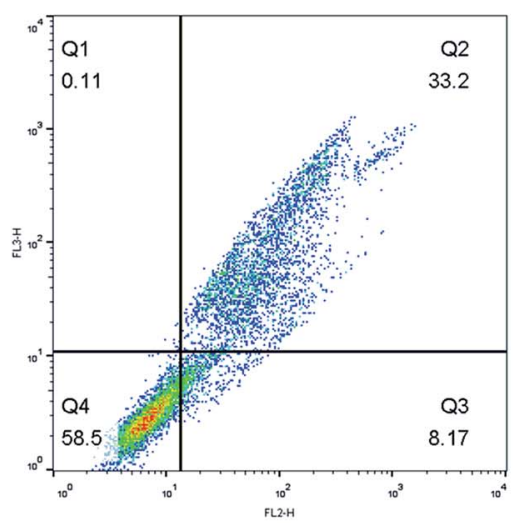

\section{$0.1 \mu \mathrm{M}$}

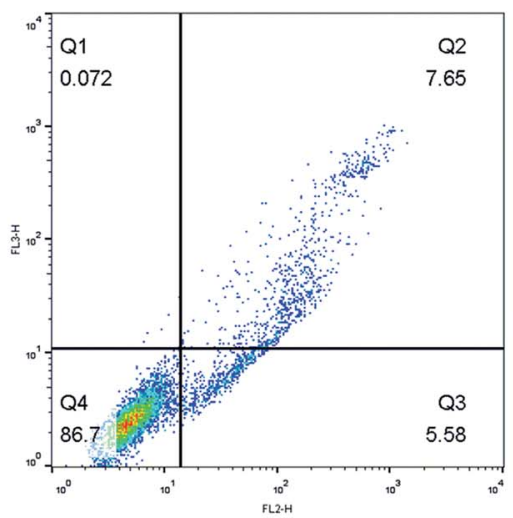

$1.0 \mu \mathbf{M}$

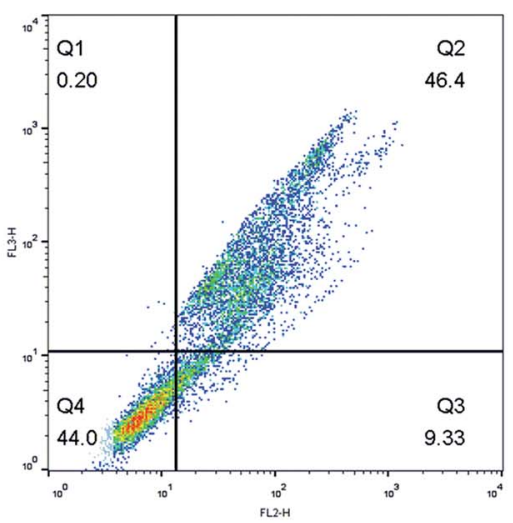

$0.2 \mu \mathrm{M}$

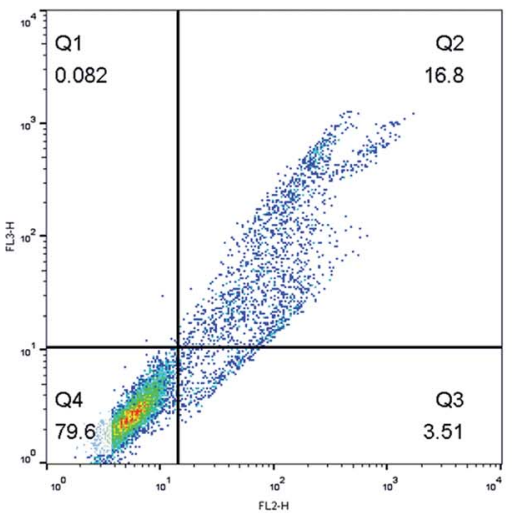

$2.0 \mu \mathbf{M}$

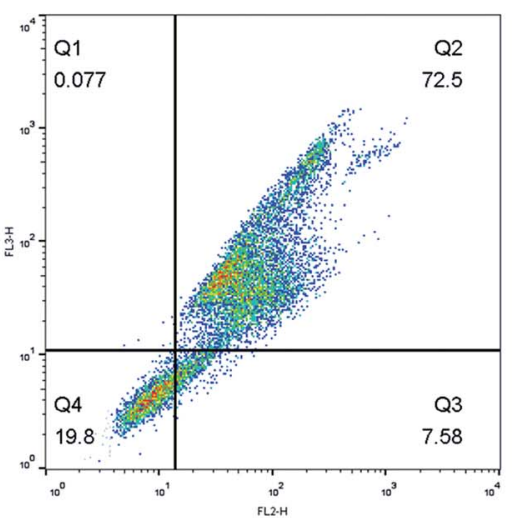

Annexin V-FITC

Fig. 6 Annexin V-FITC/propidium iodide (PI) dual staining assay. SMMC-7721 cells were treated with compound $6 \mathrm{j}$ at $0,0.1,0.2,0.5,1.0$ and 2.0 $\mu \mathrm{M}$ for $24 \mathrm{~h}$, stained with Annexin V-FITC/PI and analyzed for apoptosis through flow cytometry. The percentage of cells positive for AV and/or PI is reported in the quadrants. Cells in the lower left quadrant (AV-/PI-): live cells; lower right quadrant (AV+/PI-): early apoptotic cells; upper right quadrant $(\mathrm{AV}+/ \mathrm{PI}+)$ : late apoptotic cells; upper left quadrant $(\mathrm{AV}-/ \mathrm{PI}+)$ : necrotic cells. 


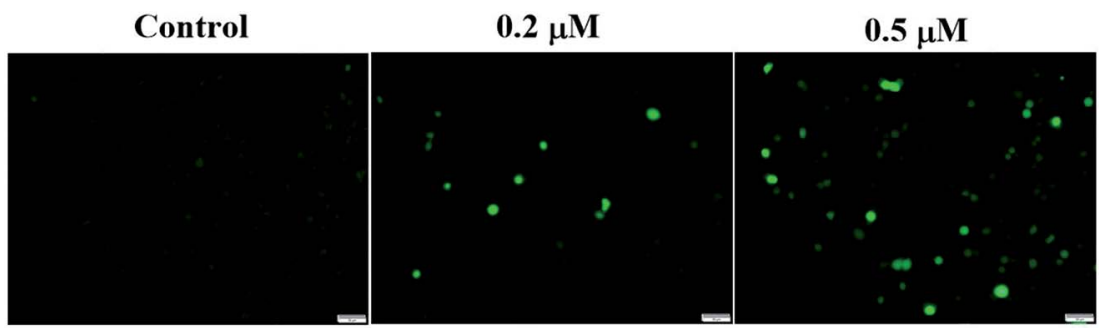

$1.0 \mu \mathrm{M}$

$2.0 \mu \mathbf{M}$

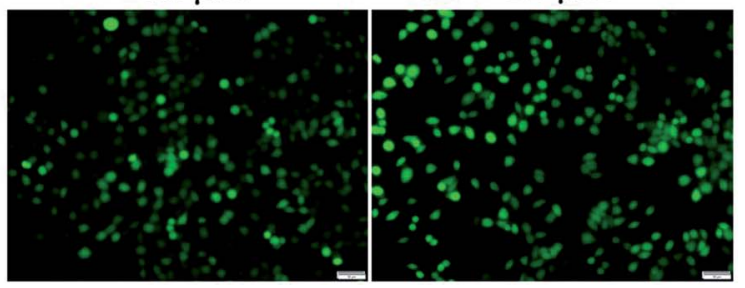

Fig. 7 Effect of compound 6j on production of reactive oxygen species (ROS) in SMMC-7721 cells. SMMC-7721 cells were stained with DCF-DA after treatment with different concentrations of compound $6 \mathrm{j}(0,0.2,0.5,1.0$ and $2.0 \mu \mathrm{M})$ for $24 \mathrm{~h}$. Fluorescent microscopic images of SMMC7721 cells were acquired using fluorescence microscopy.

observed in series $\mathbf{7 a - k}$. These results indicated that the electron-withdrawing groups $(-\mathrm{F},-\mathrm{Cl}$ and $-\mathrm{Br})$ on the benzene rings will be more beneficial to the cytotoxic activity than electron-donating ones (-Me and -OMe), and the fluoro or chloro groups on $p$-position will also be more favorable to the cytotoxicity than those on $m$ - or $o$-positions. Notably, compounds $\mathbf{6 j}, \mathbf{6 k}$ and $7 \mathbf{j}, 7 \mathbf{k}$ exhibited much more potent anticancer activities than other derivatives, indicating that the presence of $1 H$-indol-5-yl and $1 H$-indol-3-yl moieties, especially $1 H$-indol-5-yl moiety, would be more propitious to the interaction between these derivatives and their potential target.

Cell cycle analysis. Based on the results of the cytotoxic evaluation, compound $\mathbf{6 j}$ with the most potent cytotoxicity was chosen for the in-depth mechanism study. Flow cytometry was used to analyze the effects of the DAA derivative on cell growth and division. SMMC-7721 cells were treated with different concentrations of compound $6 \mathbf{j}(0,0.1,0.2$ and $0.5 \mu \mathrm{M})$ for $24 \mathrm{~h}$. Cell cycle distribution was investigated by flow cytometric analysis after staining the DNA of the treated cells with propidium iodide (PI). As shown in Fig. 2, the percentage of cells in $\mathrm{G} 2 / \mathrm{M}$ phase gradually increased from $8.86 \%(0 \mu \mathrm{M})$ to $13.65 \%$ $(0.1 \mu \mathrm{M}), 18.37 \%(0.2 \mu \mathrm{M})$ and $26.42 \%(0.5 \mu \mathrm{M})$, while the G0/G1 phase cells decreased from $65.93 \%$ to $49.30 \%$. These results suggested that compound $\mathbf{6 j}$ could arrest the cell cycle of SMMC-7721 cells at G2/M phase.

Tubulin polymerization inhibition. The significant cell growth inhibitory activity of compound $\mathbf{6 j}$ in combination with its $\mathrm{G} 2 / \mathrm{M}$ phase arresting property enlightened us to investigate its possible inhibition on tubulin polymerization. The in vitro tubulin polymerization inhibition assay was carried out by using the Tubulin Polymerization Assay Kit (Cytoskeleton, Inc., USA) according to the protocol in the manual. Porcine brain tubulin was incubated with compound $\mathbf{6 j}$ at concentrations of 5 and $10 \mu \mathrm{M}$. The positive control colchicine and negative control taxol were co-assayed at the concentration of $10 \mu \mathrm{M}$, and G-PEM buffer was used as the blank control. As shown in Fig. 3, taxol obviously increased the speed of tubulin polymerization and the final absorbance $\left(\mathrm{OD}_{340}\right)$ compared with the blank control, indicating that it could enhance the tubulin polymerization. In contrast, compound $\mathbf{6 j}$ substantially decreased the polymerization speed and the final absorbance in a dose-dependent manner, and the inhibition potency of $\mathbf{6 j}$ was stronger than colchicine at $10 \mu \mathrm{M}$ concentration. These results clearly indicate that compound $\mathbf{6 j}$ can significantly inhibit tubulin polymerization in vitro.

Immunofluorescence staining. Since the tubulin polymerization inhibitory effect of compound $\mathbf{6 j}$ has been verified, we subsequently performed the immunofluorescent staining assay to observe its effect on the intracellular microtubule system of SMMC-7721 cells. As shown in Fig. 4, the nucleus and microtubules in the untreated group appeared as the normal state characterized by the slim and fibrous microtubules, wellorganized structure (green) surrounding the uncondensed nuclei (blue). However, with increasing concentrations of compound 6j (0.1-0.5 $\mu \mathrm{M})$, the meshy microtubule networks shrank around the nuclei in a dose-dependent manner. In 0.5 $\mu \mathrm{M}$ group, most microtubule networks disappeared, and most cell nuclei became irregularly shaped and highly condensed, which is a typical characteristic of cell apoptosis. These results indicated that compound $\mathbf{6 j}$ could disrupt microtubule organizations and therefore interfered with the mitosis of SMMC-7721 cells.

Wound healing assay. Metastasis is a multistep process involving cancer cell motility and invasion which represents a key difficulty for cancer therapy. Thus, the inhibition of metastasis is vital for efficient cancer treatment. Microtubule plays an important role in cell motility and migration. As compound $\mathbf{6 j}$ inhibits tubulin polymerization, the capacity of migration inhibition was also investigated through wound healing assay. ${ }^{45}$ In this assay, standard scratches (wounds) were made in confluent monolayers of SMMC-7721 cells and incubated with different concentrations $(0,0.1,0.2$ and $0.5 \mu \mathrm{M})$ of 

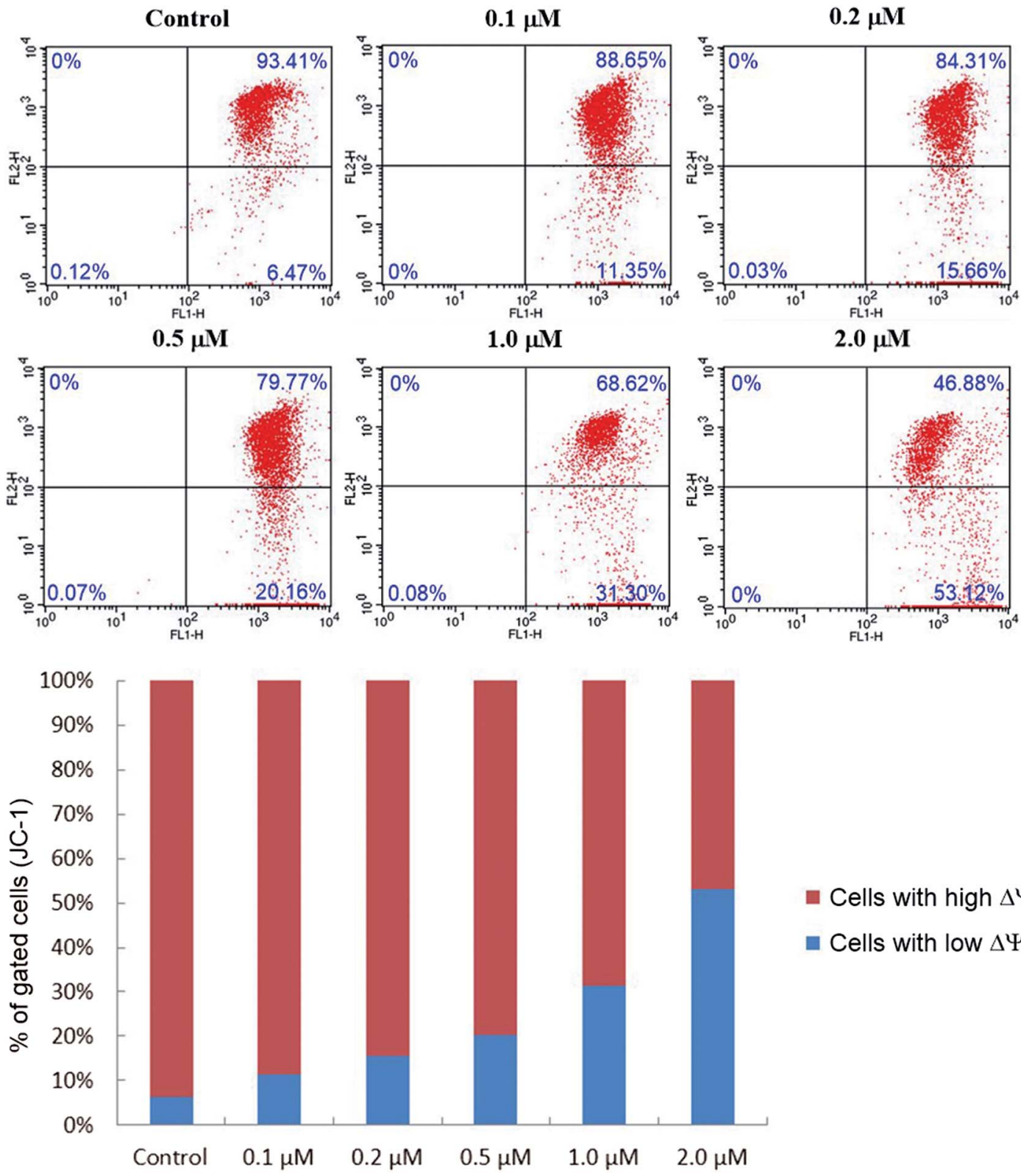

Cells with high $\Delta \Psi \mathrm{m}$

- Cells with low $\Delta \Psi \mathrm{m}$

Fig. 8 Effect of compound $6 \mathrm{j}$ on mitochondrial membrane potential $\left(\Delta \Psi_{\mathrm{m}}\right)$. SMMC-7721 cells were treated with different concentrations of compound $6 \mathrm{j}(0,0.1,0.2,0.5,1.0$ and $2.0 \mu \mathrm{M})$, incubated with $\mathrm{JC}-1$ and analyzed by flow cytometer.

compound $\mathbf{6 j}$. The migration of SMMC-7721 cells was recorded by microscopic observations at 0,24 and $48 \mathrm{~h}$. As shown in Fig. 5, there was almost complete healing of wound in control group after $48 \mathrm{~h}$, which indicated the considerable migration of cells. However, healing was strongly suppressed in 0.2 and 0.5 $\mu \mathrm{M}$ groups, suggesting that compound $\mathbf{6 j}$ could inhibit the migration of SMMC-7721 cells.

Cell apoptosis analysis. In order to investigate whether compound $\mathbf{6 j}$ could induce cell apoptosis, SMMC-7721 cells treated with different concentrations of compound $\mathbf{6 j}$ were subjected to Annexin V-FITC/propidium iodide (PI) dual staining followed by flow cytometry assay. As shown in Fig. 6, the percentage of early and late apoptotic cells (lower right quadrant, $\mathrm{AV}+/ \mathrm{PI}-$ and upper right quadrant, $\mathrm{AV}+/ \mathrm{PI}+$, respectively) significantly increased from $10.12 \%$ to $80.08 \%$ after treatment with different concentrations of compound $\mathbf{6 j}(0,0.1,0.2,0.5$, 1.0 and $2.0 \mu \mathrm{M}$ ) for $24 \mathrm{~h}$. The results suggested that compound 6j could induce the apoptosis of SMMC-7721 cells in a dosedependent manner.

ROS generation assay. Reactive oxygen species (ROS) are highly harmful elements to cells as they exert oxidative stress and finally cause cellular damage. Excessive ROS generation renders cells vulnerable to apoptosis. ${ }^{39}$ To determine whether compound $\mathbf{6 j}$ triggers ROS generation in SMMC-7721 cells to induce apoptosis, the cells were treated with different concentrations $(0,0.2,0.5,1$ and $2 \mu \mathrm{M})$ of compound $6 \mathbf{j}$ for $24 \mathrm{~h}$, and the ROS generation was evaluated using the fluorescent probe 2,7-dichlorofluorescein diacetate (DCF-DA) by fluorescence 
$\mathbf{6 j}$

(A)

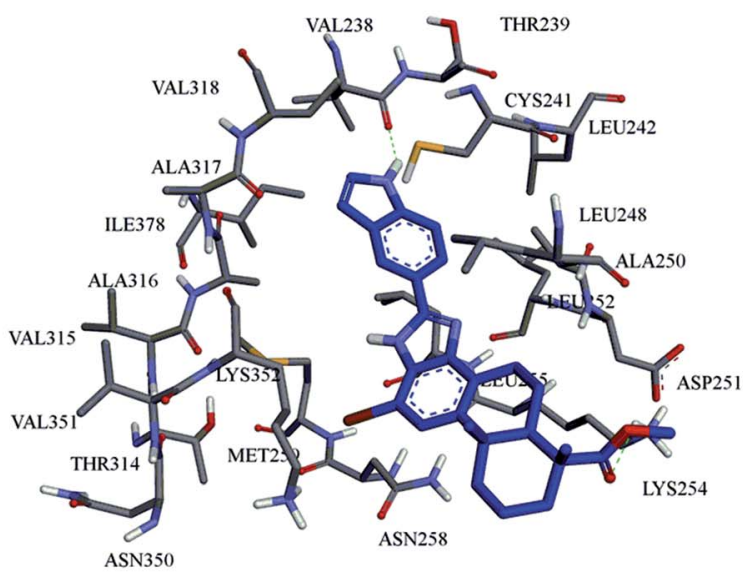

(B)

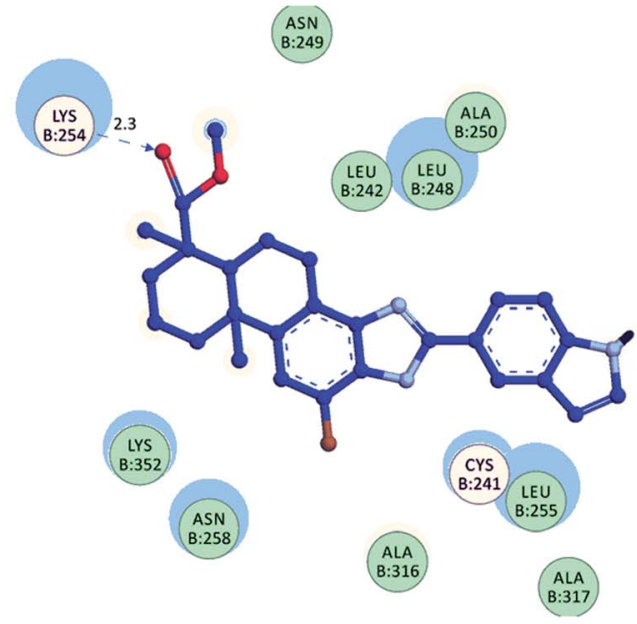

Colchicine
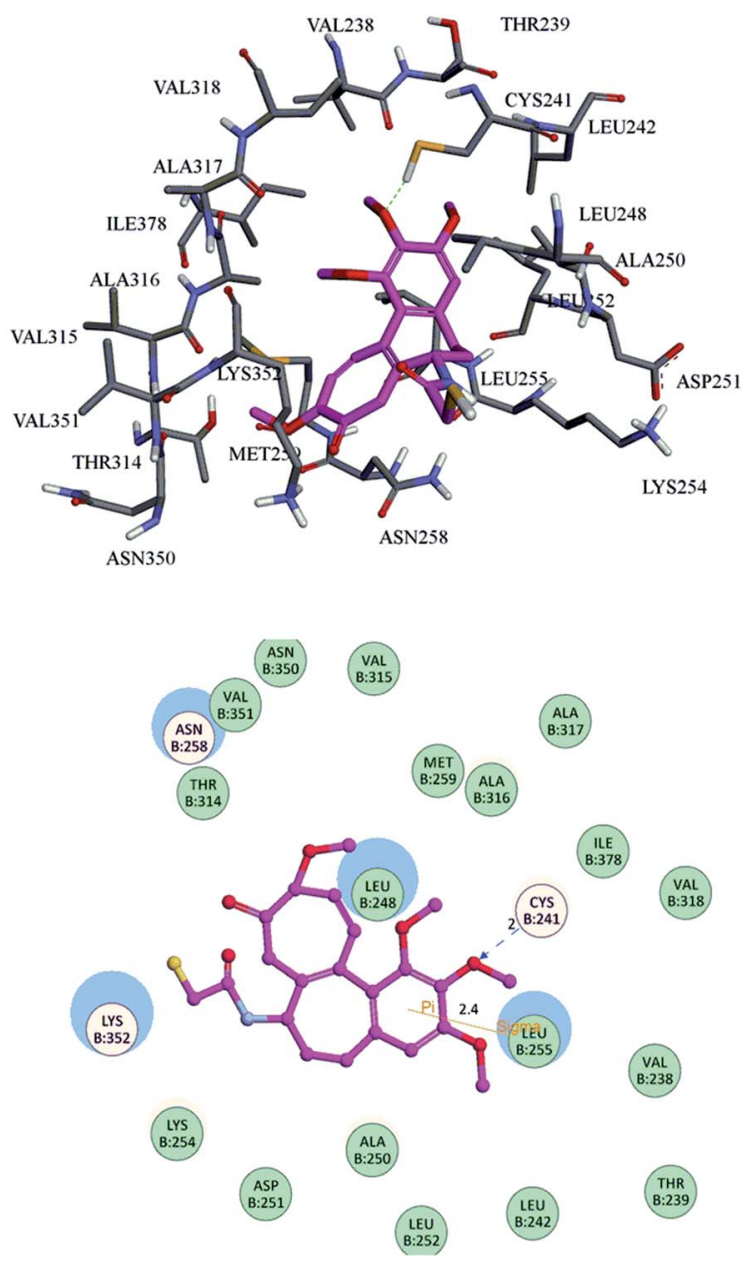

Fig. 9 The binding modes between the active conformations of compound $6 \mathrm{j}$, colchicine and tubulin. (A) The 3D diagram of interactions between the two compounds and the colchicine bing site. (B) The 2D diagram of interactions between the two compounds and the colchicine binding site. The $\mathrm{H}$-bonds were displayed as dashed arrows, and the $\sigma-\pi$ interactions were shown as orange lines.

microscopy. As shown in Fig. 7, SMMC-7721 cells treated with compound $\mathbf{6 j}$ appeared strong green fluorescence in a dosedependent manner, indicating that compound $\mathbf{6 j}$ significantly induced ROS generation. This phenomenon implied that the increment of ROS might play an important role as an early mediator in compound $\mathbf{6 j}$-induced apoptosis.

JC-1 mitochondrial membrane potential assay. As the most important organelle, mitochondria play key roles not only on supplying metabolic energy in the form of ATP, but also on regulating the signal transmission during the apoptosis of cancer cells. ${ }^{46}$ Besides, the mitochondrial dysfunction can be aroused under high ROS exposure, leading to the collapse of mitochondrial membrane potential $\left(\Delta \Psi_{\mathrm{m}}\right)$, which is a characteristic phenomenon of early apoptosis. ${ }^{47}$ In order to further investigate the apoptosis-inducing effect of target compound $\mathbf{6 j}$, mitochondrial membrane potential changes were detected using the fluorescent probe JC-1. As a lipophilic cationic dye, JC1 can easily pass through the plasma membrane into cells and accumulates in actively respiring mitochondria. In control cells, JC-1 can form aggregates in mitochondrial matrix and present high red fluorescence. However, in apoptotic cells whose mitochondrial potential has collapsed, JC-1 exists in cytosol as a monomer which emits green fluorescence. SMMC-7721 cells treated with different concentrations $(0,0.1,0.2,0.5,1.0$ and 2.0 $\mu \mathrm{M})$ of compound $\mathbf{6 j}$ for $24 \mathrm{~h}$ were stained with JC- 1 and then subjected to flow cytometry. The results were shown in Fig. 8.

As presented in Fig. 8, the percentage of cells with low $\Delta \Psi_{\mathrm{m}}$ (lower right quadrant) increased from $6.47 \%$ (control) to $11.35 \%$ $(0.1 \mu \mathrm{M}), 15.66 \%(0.2 \mu \mathrm{M}), 20.16 \%(0.5 \mu \mathrm{M}), 31.30 \%(1.0 \mu \mathrm{M})$ and $53.12 \%(2.0 \mu \mathrm{M})$, which implied that compound $6 \mathbf{j}$ could cause the decrease of mitochondrial membrane potential in a dose dependent manner, and probably induced the apoptosis of SMMC-7721 cells through the intrinsic mitochondrial-mediated pathway. ${ }^{48}$

Molecular docking. In order to investigate the binding modes of dehydroabietic acid derivatives with the tubulin protein, the top active compound $\mathbf{6 j}$ and the reference ligand colchicine were selected and docked into the colchicine-binding site between $\alpha$ - and $\beta$-tubulin protein. (PDB ID: 1SA0). ${ }^{49}$ Molecular docking studies were performed by using GLIDE docking module of Schrödinger suite 2015-1..$^{50}$ 
As shown in Fig. 9(A), it was observed that the obtained binding pose of compound $\mathbf{6 j}$ could be well accommodated inside the colchicine-binding site of tubulin. The position of the imidazole moiety and dehydroabietic acid as a core scaffold of the derivative seemed substantially consistent in the active pocket, which was surmised that this series of the DAA derivatives would adopt similar kind of binding mode interacting with the tubulin protein. Fig. 9(B) illustrate the detailed protein-inhibitor interaction of compound $\mathbf{6 j}$ with key residues of the colchicine binding site. It could been observed that the $\mathrm{N}-\mathrm{H}$ on the indole moiety of compound $\mathbf{6 j}$ established a hydrogen bond with the important active site residue Val B: 238 , while the ester group of compound $\mathbf{6 j}$ also formed a hydrogen bond with Lys B: 254, which implied that the indole and methyl ester moieties played an important role in its anti-tubulin polymerization activity. In addition, the docking results showed that compound $\mathbf{6 j}$ displayed potent interaction energy $\left(-8.888 \mathrm{kcal} \mathrm{mol}^{-1}\right)$, superior to the docking score of colchicine $\left(-6.557 \mathrm{kcal} \mathrm{mol}^{-1}\right)$, which can further proved the effectiveness of this series of DAA derivatives targeting tubulin polymerization.

\section{Conclusion}

In this work, a series of new benzimidazole derivatives of dehydroabietic acid were synthesized and evaluated for their in vitro anticancer potential against four cancer cell lines (SMMC-7721, MDA-MB-231, HeLa and CT-26). In MTT assay, compound $\mathbf{6 j}, \mathbf{6 k}$, $7 \mathbf{j}$ and $7 \mathbf{k}$ displayed significant growth inhibitory activities against several cancer cell lines comparable or superior to the positive control nocodazole. Among them, compound $\mathbf{6 j}$ exhibited the most potent anticancer activity against all test cancer cell lines and it was found to be comparatively safe towards human normal hepatocyte cell line QSG-7701. The treatment of SMMC-7721 cells with compound $\mathbf{6 j}$ led to inhibition of cell migration ability. Subsequently, the cell cycle analysis indicated that compound $\mathbf{6 j}$ could arrest SMMC-7721 cells at G2/M phase in a dose-dependent manner, which implied that compound $\mathbf{6 j}$ might interact with the microtubule systems of cancer cells. Tubulin polymerization inhibition assay and immunofluorescence staining further confirmed that compound $\mathbf{6 j}$ could considerably inhibit the polymerization of tubulin and thus disrupt the microtubule network of cancer cells. The molecular docking study provided insight into the binding mode of compound $\mathbf{6 j}$ in the colchicine-binding site of tubulin. On the other hand, Annexin V-FITC/PI dual staining assay suggested that compound $\mathbf{6 j}$ could induce the apoptosis of SMMC7721 cells. The treatment with compound $\mathbf{6 j}$ also caused the collapse of mitochondrial membrane potential and enhanced intracellular ROS levels in SMMC-7721 cells. Therefore, compound 6j represented a novel lead for potent tubulin polymerization inhibitors that paved the way for the discovery of new promising anticancer agents.

\section{Experimental}

\section{Chemistry}

Melting points were measured on an XT-4 apparatus (Taike Corp., Beijing, China) and were uncorrected. IR spectra were measured on a Nexus 870 FT-IR spectrometer, and the absorption bands were expressed in $\mathrm{cm}^{-1}$. The ESI-MS spectra were recorded on a Mariner System 5304 mass spectrometer. Elemental analyses were carried out by Elementar Vario El cube elemental analyzer. ${ }^{1} \mathrm{H}$ and ${ }^{13} \mathrm{C}$ NMR spectra were accomplished in $\mathrm{CDCl}_{3}$ or DMSO- $d_{6}$ on Bruker AV-300 and AV-500 NMR spectrometers using TMS as internal standard. Reactions and the resulted products were monitored by TLC which was carried out on TLC silica gel $60 \mathrm{~F}_{254}$ aluminium sheets from Merck KGaA, Darmstadt, Germany and visualized in UV light (254 nm). Silica gel (300-400 mesh) for column chromatography was purchased from Qingdao Marine Chemical Factory, China. The reagents (chemicals), all being of A.R. grade, were purchased from Shanghai Chemical Reagent Company (Shanghai, China) and Energy Chemical (Shanghai, China). Disproportionated rosin was provided by Zhongbang Chemicals Co., Ltd. (Zhaoqing, China), from which dehydroabietic acid (1, 97\%) was isolated according to the published method. ${ }^{51}$

\section{General procedure for the synthesis of compounds $6 a-k$}

The key intermediate (4) was synthesized from dehydroabietic acid (1) according to the procedure previously reported, ${ }^{\mathbf{4 4}}$ which was further treated as follows to afford compounds $\mathbf{6 a - k}$ and 7a-k (Scheme 1). To a solution of compound $4(0.44 \mathrm{~g}, 1.0$ $\mathrm{mmol})$ in $20 \mathrm{~mL}$ of EtOH was added reduced iron powder $(0.6 \mathrm{~g}$, $10.6 \mathrm{mmol}), \mathrm{H}_{2} \mathrm{O}(2 \mathrm{~mL})$ and 10 drops of concentrated $\mathrm{HCl}$. The mixture was stirred under reflux for $4 \mathrm{~h}$. After cooling, the mixture was filtered to remove iron powder. The solution was neutralized with aqueous $\mathrm{NaOH}\left(2 \mathrm{~mol} \mathrm{~L}^{-1}\right)$ and concentrated in vacuo. The residue was purified by column chromatography on silica gel, eluting with $\mathrm{CH}_{2} \mathrm{Cl}_{2}-\mathrm{MeOH}(20: 1, \mathrm{v} / \mathrm{v})$ to give 5 as a yellow resin $(0.22 \mathrm{~g}$, yield $57 \%)$. The spectral data of the product were in accordance with those in the previous literature. ${ }^{\mathbf{4 4}}$

To a solution of compound $5(0.66 \mathrm{~g}, 1.5 \mathrm{mmol})$ in $20 \mathrm{~mL}$ of anhydrous EtOH was added p-toluenesulfonic acid $(25.8 \mathrm{mg}$, $0.15 \mathrm{mmol}$ ) and $2.2 \mathrm{mmol}$ of different substituted arylaldehyde. The reaction mixture was stirred at $85{ }^{\circ} \mathrm{C}$ for $24 \mathrm{~h}$ under nitrogen atmosphere and monitored by TLC. At the end of reaction, the mixture was poured into $200 \mathrm{~mL}$ of ice-cold water, which was extracted with EtOAc for three times $(3 \times 200 \mathrm{~mL})$. The organic phase was combined, washed with water, saturated $\mathrm{NaHCO}_{3}$ solution and brine, dried over anhydrous $\mathrm{Na}_{2} \mathrm{SO}_{4}$ and then concentrated in vacuo to give the crude product, which was purified by silica gel chromatography (petroleum ether-acetone $100: 1-10: 1, \mathrm{v} / \mathrm{v}$ ) to afford compounds $6 \mathbf{a}-\mathbf{k}$.

Methyl 2'-phenyl-12-bromo-13,14-imidazolyl-deisopropyldehydroabietate (6a). White powder solid; mp 123-125 ${ }^{\circ} \mathrm{C}$; yield: $73.8 \%$; ${ }^{1} \mathrm{H}$ NMR $\left(300 \mathrm{MHz}, \mathrm{CDCl}_{3}\right) \delta: 1.28(\mathrm{~s}, 3 \mathrm{H}), 1.31(\mathrm{~s}$, $3 \mathrm{H}), 1.50-1.81(\mathrm{~m}, 7 \mathrm{H}), 1.92(\mathrm{~m}, 1 \mathrm{H}), 2.30-2.37$ (m, 2H), $3.09(\mathrm{~m}$, $1 \mathrm{H}), 3.17$ (brs, 1H), 3.68 (s, 3H), 7.35 (s, 1H), 7.45-7.48 (m, 3H), $8.04(\mathrm{dd}, J=7.9,1.8 \mathrm{~Hz}, 2 \mathrm{H}) ;{ }^{13} \mathrm{C} \mathrm{NMR}\left(75 \mathrm{MHz} \mathrm{CDCl}_{3}\right) \delta: 16.6$, 18.7, 21.1, 25.3, 25.4, 36.8, 37.7, 38.6, 45.3, 47.9, 52.2, 104.7, 121.2 , 122.5, 126.9, 129.0, 129.8, 130.3, 138.3, 139.8, 145.7, 151.5, 179.2; IR (KBr, cm $\left.{ }^{-1}\right): 3303,2930,2864,1726,1619,1579$, 1470, 1454, 1385, 1254, 1193, 1129, 1035, 857, 737; MS (ESI): $m / z$ 
467.1 [M + H] $]^{+}$; anal. calcd for $\mathrm{C}_{25} \mathrm{H}_{27} \mathrm{BrN}_{2} \mathrm{O}_{2}$ : C 64.24; $\mathrm{H}$ 5.82; N 5.99; found: C 64.31; H 5.78, N 6.03.

Methyl $\quad 2^{\prime}$-(p-tolyl)-12-bromo-13,14-imidazolyl-deisopropyldehydroabietate (6b). White powder solid; mp $143-145{ }^{\circ} \mathrm{C}$; yield: $71.6 \% ;{ }^{1} \mathrm{H}$ NMR $\left(500 \mathrm{MHz}, \mathrm{CDCl}_{3}\right) \delta: 1.27(\mathrm{~s}, 3 \mathrm{H}), 1.31(\mathrm{~s}$, $3 \mathrm{H}), 1.50-1.81(\mathrm{~m}, 7 \mathrm{H}), 1.92(\mathrm{~m}, 1 \mathrm{H}), 2.30-2.36(\mathrm{~m}, 2 \mathrm{H}), 2.41(\mathrm{~s}$, $3 \mathrm{H}), 3.07$ (brs, 1H), 3.17 (brs, 1H), 3.68 (s, 3H), 7.28 (d, $J=$ $7.9 \mathrm{~Hz}, 2 \mathrm{H}), 7.33(\mathrm{~s}, 1 \mathrm{H}), 7.93(\mathrm{~d}, J=8.0 \mathrm{~Hz}, 2 \mathrm{H}) ;{ }^{13} \mathrm{C}$ NMR $(75$ $\mathrm{MHz}, \mathrm{CDCl}_{3}$ ) $\delta: 16.6,18.7,21.1,21.6,25.4,36.8,37.6,38.6,45.2$, 47.9, 52.2, 104.6, 122.4, 126.8, 126.9, 129.8, 134.1, 139.2, 140.7, 145.6, 151.7, 179.2; IR $\left(\mathrm{KBr}, \mathrm{cm}^{-1}\right): 3308,2929,2867,1725,1623$, 1579, 1476, 1429, 1380, 1253, 1190, 1128, 1037, 824, 726; MS (ESI): $m / z 481.1[\mathrm{M}+\mathrm{H}]^{+}$; anal. calcd for $\mathrm{C}_{26} \mathrm{H}_{29} \mathrm{BrN}_{2} \mathrm{O}_{2}$ : C 64.87; H 6.07; N 5.82; found: C 64.81; H 6.13, N 5.76.

Methyl 2'-(4-fluorophenyl)-12-bromo-13,14-imidazolyldeisopropyl-dehydroabietate (6c). White powder solid; $\mathrm{mp}$ 149-151 ${ }^{\circ} \mathrm{C}$; yield: $82.6 \% ;{ }^{1} \mathrm{H}$ NMR $\left(500 \mathrm{MHz}, \mathrm{CDCl}_{3}\right) \delta: 1.28(\mathrm{~s}$, $3 \mathrm{H}), 1.32(\mathrm{~s}, 3 \mathrm{H}), 1.50-1.81(\mathrm{~m}, 7 \mathrm{H}), 1.92(\mathrm{~m}, 1 \mathrm{H}), 2.30-2.36(\mathrm{~m}$, $2 \mathrm{H}), 3.06(\mathrm{brs}, 1 \mathrm{H}), 3.17(\mathrm{brs}, 1 \mathrm{H}), 3.68(\mathrm{~s}, 3 \mathrm{H}), 7.16(\mathrm{t}, J=8.5 \mathrm{~Hz}$, $2 \mathrm{H}), 7.35(\mathrm{~s}, 1 \mathrm{H}), 8.02(\mathrm{dd}, J=8.5,5.2 \mathrm{~Hz}, 2 \mathrm{H}) ;{ }^{13} \mathrm{C}$ NMR $(75$ $\left.\mathrm{MHz}, \mathrm{CDCl}_{3}\right) \delta: 16.6,18.7,21.1,25.3,25.4,36.8,37.7,38.6,45.2$, $47.9,52.2,103.0,116.2(\mathrm{~d}, J=21.9 \mathrm{~Hz}), 122.6,126.1,128.9(\mathrm{~d}, J=$ $8.5 \mathrm{~Hz}$ ), 139.2, 140.6, 145.9, 150.6, 164.1 (d, $J=249.1 \mathrm{~Hz}), 179.3$; IR $\left(\mathrm{KBr}, \mathrm{cm}^{-1}\right): 3313,2931,2863,1729,1620,1607,1493,1471$, 1431, 1381, 1250, 1160, 1128, 841, 736; MS (ESI): $m / z 485.1$ [M + $\mathrm{H}]^{+}$; anal. calcd for $\mathrm{C}_{25} \mathrm{H}_{26} \mathrm{BrFN}_{2} \mathrm{O}_{2}$ : C 61.86; $\mathrm{H} \mathrm{5.40;} \mathrm{N} \mathrm{5.77;}$ found: C 61.84; $\mathrm{H} 5.42$, N 5.78.

Methyl 2'-(3-fluorophenyl)-12-bromo-13,14-imidazolyldeisopropyl-dehydroabietate (6d). Yellow powder solid; $\mathrm{mp}$ 142-144 ${ }^{\circ} \mathrm{C}$; yield: $74.2 \%$; ${ }^{1} \mathrm{H}$ NMR $\left(300 \mathrm{MHz}, \mathrm{CDCl}_{3}\right) \delta: 1.28(\mathrm{~s}$, $3 \mathrm{H}), 1.32(\mathrm{~s}, 3 \mathrm{H}), 1.50-1.82(\mathrm{~m}, 7 \mathrm{H}), 1.93(\mathrm{~m}, 1 \mathrm{H}), 2.30-2.36(\mathrm{~m}$, $2 \mathrm{H}), 3.07(\mathrm{~m}, 1 \mathrm{H}), 3.16(\mathrm{~m}, 1 \mathrm{H}), 3.69(\mathrm{~s}, 3 \mathrm{H}), 7.16(\mathrm{t}, J=8.4 \mathrm{~Hz}$, 1H), $7.36(\mathrm{~s}, 1 \mathrm{H}), 7.46(\mathrm{~m}, 1 \mathrm{H}), 7.79(\mathrm{~d}, J=8.1 \mathrm{~Hz}, 2 \mathrm{H}) ;{ }^{13} \mathrm{C} \mathrm{NMR}$ $\left(75 \mathrm{MHz}, \mathrm{CDCl}_{3}\right) \delta: 16.6,18.7,21.1,25.3,25.4,36.8,37.7,38.6$, 45.3, 47.9, 52.2, 105.9, 114.1 (d, $J=23.4 \mathrm{~Hz}), 117.3(\mathrm{~d}, J=21.2$ $\mathrm{Hz}), 122.4(\mathrm{~d}, J=2.8 \mathrm{~Hz}), 122.9,127.3(\mathrm{~d}, J=7.1 \mathrm{~Hz}), 130.8(\mathrm{~d}, J$ $=8.2 \mathrm{~Hz}), 136.1,140.2,145.2,147.9,164.1(\mathrm{~d}, J=249.1 \mathrm{~Hz})$, 179.3; IR ( $\left.\mathrm{KBr}, \mathrm{cm}^{-1}\right)$ : 3285, 2926, 2854, 1724, 1665, 1586, 1461, 1255, 1198, 1129, 861, 790; MS (ESI): $m / z 485.1[\mathrm{M}+\mathrm{H}]^{+}$; anal. calcd for $\mathrm{C}_{25} \mathrm{H}_{26} \mathrm{BrFN}_{2} \mathrm{O}_{2}$ : C 61.86; $\mathrm{H} 5.40$; N 5.77; found: C 61.93; H 5.36, N 5.71.

Methyl 2'-(2-fluorophenyl)-12-bromo-13,14-imidazolyldeisopropyl-dehydroabietate (6e). Yellow powder solid; $\mathrm{mp}$ 138-139 ${ }^{\circ} \mathrm{C}$; yield: $72.7 \% ;{ }^{1} \mathrm{H}$ NMR $\left(300 \mathrm{MHz}, \mathrm{CDCl}_{3}\right) \delta: 1.28(\mathrm{~s}$, $3 \mathrm{H}), 1.32(\mathrm{~s}, 3 \mathrm{H}), 1.50-1.82(\mathrm{~m}, 7 \mathrm{H}), 1.95(\mathrm{~m}, 1 \mathrm{H}), 2.31-2.37(\mathrm{~m}$, $2 \mathrm{H}), 3.07-3.16(\mathrm{~m}, 2 \mathrm{H}), 3.69(\mathrm{~s}, 3 \mathrm{H}), 7.20(\mathrm{~m}, 1 \mathrm{H}), 7.29-7.34(\mathrm{~m}$, $2 \mathrm{H}), 7.40-7.48(\mathrm{~m}, 2 \mathrm{H}) ;{ }^{13} \mathrm{C}$ NMR $\left(75 \mathrm{MHz}, \mathrm{CDCl}_{3}\right) \delta: 16.6,18.7$, 21.1, 25.3, 36.7, 37.7, 38.6, 45.3, 47.8, 52.2, 106.4, 116.2 (d, $J=$ $23.0 \mathrm{~Hz}), 122.8,125.3(\mathrm{~d}, J=2.9 \mathrm{~Hz}), 130.8(\mathrm{~d}, J=23.8 \mathrm{~Hz}), 131.8$ $(\mathrm{d}, J=9.1 \mathrm{~Hz}), 137.8,139.8,145.9,151.8,160.4(\mathrm{~d}, J=245.6 \mathrm{~Hz})$, 179.1; IR (KBr, cm ${ }^{-1}$ ): 3379, 2921, 2780, 2360, 1712, 1455, 1245, 1128, 1045, 880, 758, 692. MS (ESI): $m / z 486.4[\mathrm{M}+\mathrm{H}]^{+}$; anal. calcd (\%) for $\mathrm{C}_{25} \mathrm{H}_{26} \mathrm{BrFN}_{2} \mathrm{O}_{2}$ : C, 61.86; $\mathrm{H}, 5.40 ; \mathrm{N}, 5.77$; found (\%): C, 61.92; H, 5.37; N, 5.82.

Methyl 2'-(4-chlorophenyl)-12-bromo-13,14-imidazolyldeisopropyl-dehydroabietate (6f). Yellow powder solid; $\mathrm{mp}$ 139-141 ${ }^{\circ} \mathrm{C}$; yield: $81.8 \% ;{ }^{1} \mathrm{H}$ NMR $\left(300 \mathrm{MHz}, \mathrm{CDCl}_{3}\right) \delta: 1.28(\mathrm{~s}$,
$3 \mathrm{H}), 1.32(\mathrm{~s}, 3 \mathrm{H}), 1.50-2.10(\mathrm{~m}, 7 \mathrm{H}), 1.93(\mathrm{~m}, 1 \mathrm{H}), 2.30-2.37(\mathrm{~m}$, $2 \mathrm{H}), 3.05-3.16(\mathrm{~m}, 2 \mathrm{H}), 3.68(\mathrm{~s}, 3 \mathrm{H}), 7.36(\mathrm{~s}, 1 \mathrm{H}), 7.46(\mathrm{~d}, J=$ $8.1 \mathrm{~Hz}, 2 \mathrm{H}), 7.98(\mathrm{~d}, J=8.3 \mathrm{~Hz}, 2 \mathrm{H}) ;{ }^{13} \mathrm{C} \mathrm{NMR}\left(75 \mathrm{MHz}, \mathrm{CDCl}_{3}\right) \delta$ : 16.6, 18.7, 21.1, 25.3, 25.4, 36.8, 37.7, 38.5, 45.2, 47.9, 52.2, $105.1,122.8,128.1,128.3,129.3,136.4,139.7,141.3,146.0$, 150.3, 179.3; IR (KBr, cm $\left.{ }^{-1}\right): 3355,2924,2852,1724,1666,1577$, 1494, 1454, 1244, 1126, 1046, 1015, 764, 732. MS (ESI): $\mathrm{m} / z 501.1$ $[\mathrm{M}+\mathrm{H}]^{+}$; anal. calcd (\%) for $\mathrm{C}_{25} \mathrm{H}_{26} \mathrm{BrClN}_{2} \mathrm{O}_{2}$ : C, 59.83; H, 5.22; N, 5.58; found (\%): C, 59.76; H, 5.27; N, 5.62.

Methyl 2'-(2-chlorophenyl)-12-bromo-13,14-imidazolyldeisopropyl-dehydroabietate (6g). Yellow powder solid; $\mathrm{mp}$ 142-143 ${ }^{\circ} \mathrm{C}$; yield: $75.8 \% ;{ }^{1} \mathrm{H}$ NMR $\left(300 \mathrm{MHz}, \mathrm{CDCl}_{3}\right) \delta: 1.29(\mathrm{~s}$, $3 \mathrm{H}), 1.32(\mathrm{~s}, 3 \mathrm{H}), 1.50-2.10(\mathrm{~m}, 7 \mathrm{H}), 1.94(\mathrm{~m}, 1 \mathrm{H}), 2.30-2.42(\mathrm{~m}$, $2 \mathrm{H}), 3.02-3.30(\mathrm{~m}, 2 \mathrm{H}), 3.69(\mathrm{~s}, 3 \mathrm{H}), 7.39(\mathrm{~s}, 1 \mathrm{H}), 7.41-7.45(\mathrm{~m}$, $2 \mathrm{H}), 7.49(\mathrm{dd}, J=7.2,1.8 \mathrm{~Hz}, 1 \mathrm{H}), 8.43(\mathrm{~d}, J=7.2 \mathrm{~Hz}, 1 \mathrm{H}) ;{ }^{13} \mathrm{C}$ $\operatorname{NMR}\left(75 \mathrm{MHz}, \mathrm{CDCl}_{3}\right) \delta: 16.6,18.7,21.0,25.34,25.36,36.7,37.7$, 38.6, 45.2, 47.8, 52.1, 105.8, 122.8, 127.6, 128.4, 129.0, 130.6, 131.1, 132.5, 138.7, 141.1, 145.8, 150.4, 179.1; IR (KBr, $\left.\mathrm{cm}^{-1}\right)$ : 3301, 2929, 2866, 1725, 1617, 1578, 1537, 1451, 1404, 1250, 1192, 1129, 1052, 1035, 962, 764, 735. MS (ESI): $m / z 501.1[\mathrm{M}+$ $\mathrm{H}]^{+}$; anal. calcd (\%) for $\mathrm{C}_{25} \mathrm{H}_{26} \mathrm{BrClN}_{2} \mathrm{O}_{2}$ : C, 59.83; H, 5.22; N, 5.58; found (\%): C, 59.88; H, 5.29; N, 5.51 .

Methyl 2'-(4-bromophenyl)-12-bromo-13,14-imidazolyldeisopropyl-dehydroabietate (6h). Yellow powder solid; $\mathrm{mp}$ 141-142 ${ }^{\circ} \mathrm{C}$; yield: $74.2 \% ;{ }^{1} \mathrm{H}$ NMR $\left(300 \mathrm{MHz}, \mathrm{CDCl}_{3}\right) \delta: 1.28(\mathrm{~s}$, $3 \mathrm{H}), 1.32(\mathrm{~s}, 3 \mathrm{H}), 1.50-2.10(\mathrm{~m}, 8 \mathrm{H}), 2.30-2.37(\mathrm{~m}, 2 \mathrm{H}), 3.05-3.17$ $(\mathrm{m}, 2 \mathrm{H}), 3.68(\mathrm{~s}, 3 \mathrm{H}), 7.36(\mathrm{~s}, 1 \mathrm{H}), 7.61(\mathrm{~d}, J=8.2 \mathrm{~Hz}, 2 \mathrm{H}), 7.92$ (d, $J=8.3 \mathrm{~Hz}, 2 \mathrm{H}) ;{ }^{13} \mathrm{C}$ NMR $\left(75 \mathrm{MHz}, \mathrm{CDCl}_{3}\right) \delta: 16.6,18.7,21.1$, 25.4, 25.5, 36.8, 37.7, 38.5, 45.2, 47.9, 52.2, 105.2, 122.8, 124.9, 128.4, 129.0, 131.1, 132.2, 136.9, 139.2, 145.2, 150.5, 179.3; IR $\left(\mathrm{KBr}, \mathrm{cm}^{-1}\right): 3317,2923,2852,1725,1468,1428,1382,1254$, 1191, 1129, 1072, 1038, 1010, 834, 727. MS (ESI): $\mathrm{m} / z$ 545.0 [M + $\mathrm{H}]^{+}$; anal. calcd (\%) for $\mathrm{C}_{25} \mathrm{H}_{26} \mathrm{Br}_{2} \mathrm{~N}_{2} \mathrm{O}_{2}$ : C, 54.96; $\mathrm{H}, 4.80 ; \mathrm{N}$, 5.13; found (\%): C, 55.03; H, 4.84; N, 5.08.

Methyl 2'-(4-methoxyphenyl)-12-bromo-13,14-imidazolyldeisopropyl-dehydroabietate (6i). White powder solid; $\mathrm{mp}$ 140-142 ${ }^{\circ} \mathrm{C}$; yield: $61.3 \% ;{ }^{1} \mathrm{H}$ NMR $\left(500 \mathrm{MHz}, \mathrm{CDCl}_{3}\right) \delta: 1.27(\mathrm{~s}$, $3 \mathrm{H}), 1.31(\mathrm{~s}, 3 \mathrm{H}), 1.50-1.81(\mathrm{~m}, 7 \mathrm{H}), 1.91(\mathrm{~m}, 1 \mathrm{H}), 2.33(\mathrm{~m}, 2 \mathrm{H})$, $3.03(\mathrm{~m}, 1 \mathrm{H}), 3.17(\mathrm{brs}, 1 \mathrm{H}), 3.67(\mathrm{~s}, 3 \mathrm{H}), 3.86(\mathrm{~s}, 3 \mathrm{H}), 6.98(\mathrm{~d}, J=$ $8.5 \mathrm{~Hz}, 2 \mathrm{H}), 7.31(\mathrm{~s}, 1 \mathrm{H}), 7.98(\mathrm{~d}, J=8.4 \mathrm{~Hz}, 2 \mathrm{H}) ;{ }^{13} \mathrm{C}$ NMR $(75$ $\left.\mathrm{MHz}, \mathrm{CDCl}_{3}\right) \delta: 16.6,18.7,21.1,25.3,25.4,36.8,37.6,38.5,45.2$, 47.8, 52.2, 55.5, 105.9, 114.4, 122.2, 122.4, 128.5, 136.2, 138.7, 145.4, 151.9, 161.3, 179.3; IR (KBr, $\left.\mathrm{cm}^{-1}\right): 3331,2934,2863$, 1724, 1613, 1581, 1496, 1474, 1435, 1385, 1254, 1178, 1129, 1033, 838, 737; MS (ESI): $m / z[\mathrm{M}+\mathrm{H}]^{+}: 497.1$; anal. calcd for $\mathrm{C}_{26} \mathrm{H}_{29} \mathrm{BrN}_{2} \mathrm{O}_{3}$ : C 62.78; H 5.88; N 5.63; found: C 62.70; H 5.93, N 5.67 .

Methyl 2'-(1H-indol-5-yl)-12-bromo-13,14-imidazolyldeisopropyl-dehydroabietate (6j). White powder solid; $\mathrm{mp}$ 179-181 ${ }^{\circ} \mathrm{C}$; yield: $74.4 \% ;{ }^{1} \mathrm{H}$ NMR $\left(500 \mathrm{MHz}, \mathrm{CDCl}_{3}\right) \delta: 1.28(\mathrm{~s}$, $3 \mathrm{H}), 1.32(\mathrm{~s}, 3 \mathrm{H}), 1.50-1.82(\mathrm{~m}, 7 \mathrm{H}), 1.94(\mathrm{~m}, 1 \mathrm{H}), 2.31-2.37(\mathrm{~m}$, $2 \mathrm{H}), 3.09(\mathrm{~m}, 1 \mathrm{H}), 3.21$ (brs, 1H), $3.69(\mathrm{~s}, 3 \mathrm{H}), 6.62(\mathrm{~s}, 1 \mathrm{H}), 7.28$ (s, 1H), $7.32(\mathrm{~s}, 1 \mathrm{H}), 7.45(\mathrm{~d}, J=8.1 \mathrm{~Hz}, 1 \mathrm{H}), 7.90(\mathrm{~d}, J=8.2 \mathrm{~Hz}$, 1H), 8.29 (s, 1H), 8.44 (brs, $1 \mathrm{H}) ;{ }^{13} \mathrm{C}$ NMR $\left(75 \mathrm{MHz}, \mathrm{CDCl}_{3}\right) \delta$ : 16.6, 18.7, 21.1, 25.3, 25.4, 36.8, 37.5, 38.5, 45.2, 47.8, 52.2, 103.1, 107.6, 111.8, 116.3, 119.8, 121.1, 121.2, 121.9, 125.8, 128.0, 136.2, 137.0, 139.8, 145.2, 153.9, 179.5; IR (KBr, $\left.\mathrm{cm}^{-1}\right)$ : 
3325, 2929, 2866, 1703, 1620, 1581, 1542, 1452, 1397, 1250, 1130, 1035, 811, 735; MS (ESI): $m / z 506.1[\mathrm{M}+\mathrm{H}]^{+}$; anal. calcd for $\mathrm{C}_{27} \mathrm{H}_{28} \mathrm{BrN}_{3} \mathrm{O}_{2}$ : C 64.03; H 5.57; N 8.30; found: C 64.09; H 5.53, N 8.37 .

Methyl 2'-(1H-indol-3-yl)-12-bromo-13,14-imidazolyldeisopropyl-dehydroabietate (6k). White powder solid; mp 139-140 ${ }^{\circ} \mathrm{C}$; yield: $60.2 \% ;{ }^{1} \mathrm{H}$ NMR (300 MHz, DMSO- $\left.d_{6}\right) \delta: 1.23$ (s, 3H), 1.25 (s, 3H), 1.36-1.51 (m, 2H), 1.63-2.00 (m, 5H), 2.15$2.39(\mathrm{~m}, 2 \mathrm{H}), 2.37(\mathrm{~m}, 1 \mathrm{H}), 2.90(\mathrm{~m}, 1 \mathrm{H}), 3.06(\mathrm{~m}, 1 \mathrm{H}), 3.64(\mathrm{~s}$, $3 \mathrm{H}), 7.23(\mathrm{~m}, 3 \mathrm{H}), 7.48(\mathrm{~d}, J=5.2 \mathrm{~Hz}, 1 \mathrm{H}), 8.25(\mathrm{~s}, 1 \mathrm{H}), 8.56(\mathrm{~s}$, 1H), $11.60(\mathrm{~s}, 1 \mathrm{H}) ;{ }^{13} \mathrm{C} \mathrm{NMR}\left(75 \mathrm{MHz}, \mathrm{CDCl}_{3}\right) \delta: 16.6,18.7,21.1$, 25.4, 36.8, 37.6, 38.6, 45.2, 47.8, 52.2, 106.0, 106.9, 112.2, 120.1, $121.4,121.8,123.1,125.1,126.1,129.7,135.7,136.5,138.5$, 145.3, 149.4, 179.3; IR (KBr, $\mathrm{cm}^{-1}$ ): 3393, 3327, 2929, 2870, 1724, 1705, 1627, 1587, 1542, 1456, 1390, 1247, 1129, 1023, 821, 743; MS (ESI): $m / z 506.1[\mathrm{M}+\mathrm{H}]^{+}$; anal. calcd for $\mathrm{C}_{27} \mathrm{H}_{28} \mathrm{BrN}_{3} \mathrm{O}_{2}: \mathrm{C}$ 64.03; H 5.57; N 8.30; found: C 63.95; H 5.64, N 8.26.

\section{General procedure for the synthesis of compounds $7 a-k$}

To a solution of compound $6(0.15 \mathrm{mmol})$ in $22 \mathrm{~mL}$ of $\mathrm{THF} / \mathrm{H}_{2} \mathrm{O}$ (10:1) was added 3,4,5-trimethoxyphenylboronic acid (63 mg, $0.3 \mathrm{mmol}), \mathrm{K}_{2} \mathrm{CO}_{3}(415 \mathrm{mg}, 3 \mathrm{mmol})$ and $\operatorname{Pd}\left(\mathrm{PPh}_{3}\right)_{4}(17 \mathrm{mg}$, $0.015 \mathrm{mmol}$ ). The reaction mixture was stirred at $85{ }^{\circ} \mathrm{C}$ for $24 \mathrm{~h}$ under nitrogen atmosphere and monitored by TLC. Subsequently, the mixture was poured into ice-cold water $(200 \mathrm{~mL})$ and extracted EtOAc for three times $(3 \times 200 \mathrm{~mL})$. The organic layer was combined, washed with water, saturated $\mathrm{NaHCO}_{3}$ solution and brine, dried over anhydrous $\mathrm{Na}_{2} \mathrm{SO}_{4}$ and then concentrated in vacuo to give the crude product, which was purified by silica gel chromatography (petroleum ether-acetone $100: 1-10: 1, \mathrm{v} / \mathrm{v})$ to afford compounds $7 \mathbf{a}-\mathbf{k}$.

Methyl 2'-phenyl-12-(3,4,5-trimethoxyphenyl)-13,14imidazolyl-deisopropyl-dehydroabietate (7a). White powder solid; mp 153-155 ${ }^{\circ} \mathrm{C}$; yield: $62.5 \%$; ${ }^{1} \mathrm{H}$ NMR (500 $\mathrm{MHz}, \mathrm{CDCl}_{3}$ ) $\delta: 1.35(\mathrm{~s}, 6 \mathrm{H}), 1.50-1.82(\mathrm{~m}, 7 \mathrm{H}), 2.00(\mathrm{~m}, 1 \mathrm{H}), 2.42(\mathrm{~d}, J=$ $12.4 \mathrm{~Hz}, 1 \mathrm{H}), 2.47$ (m, 1H), 3.07 (brs, $1 \mathrm{H}), 3.14(\mathrm{~m}, 1 \mathrm{H}), 3.70(\mathrm{~s}$, $3 \mathrm{H}), 3.93(\mathrm{~s}, 6 \mathrm{H}), 3.96(\mathrm{~s}, 3 \mathrm{H}), 6.80(\mathrm{~s}, 2 \mathrm{H}), 7.36(\mathrm{~s}, 1 \mathrm{H}), 7.40-7.49$ (m, 3H), 8.02 (brs, $2 \mathrm{H}) ;{ }^{13} \mathrm{C}$ NMR (75 MHz, $\mathrm{CDCl}_{3}$ ) $\delta: 16.7,18.8$, 21.3, 25.5, 25.6, 36.8, 37.6, 38.7, 45.5, 48.0, 52.1, 56.5, 61.1, $106.2,118.9,119.8,126.2,126.6,128.8,129.1,130.1,134.9$, 137.6, 140.3, 140.7, 147.6, 151.1, 153.7, 179.2; IR (KBr, $\left.\mathrm{cm}^{-1}\right)$ : 3318, 2935, 2870, 1724, 1581, 1496, 1454, 1378, 1246, 1180, 1128, 1023, 833, 735; MS (ESI): $m / z 555.3[\mathrm{M}+\mathrm{H}]^{+}$; anal. calcd for $\mathrm{C}_{34} \mathrm{H}_{38} \mathrm{~N}_{2} \mathrm{O}_{5}$ : C 73.62; $\mathrm{H} 6.91$; N 5.05; found: $\mathrm{C} 73.69 ; \mathrm{H} \mathrm{6.88,} \mathrm{N}$ 5.10.

Methyl 2'-(p-tolyl)-12-(3,4,5-trimethoxyphenyl)-13,14imidazolyl-deisopropyl-dehydroabietate (7b). White powder solid; mp $133-135{ }^{\circ} \mathrm{C}$; yield: $56.3 \%$; ${ }^{1} \mathrm{H}$ NMR (500 $\mathrm{MHz}, \mathrm{CDCl}_{3}$ ) $\delta: 1.26(\mathrm{~s}, 3 \mathrm{H}), 1.34(\mathrm{~s}, 3 \mathrm{H}), 1.50-1.86(\mathrm{~m}, 7 \mathrm{H}), 2.01(\mathrm{~m}, 1 \mathrm{H}), 2.41$ (s, 3H), 2.45 (m, 2H), 3.19 (brs, 1H), 3.28 (brs, $1 \mathrm{H}), 3.69$ (s, 3H), $3.93(\mathrm{~s}, 3 \mathrm{H}), 3.95(\mathrm{~s}, 6 \mathrm{H}), 6.82(\mathrm{~s}, 2 \mathrm{H}), 7.29(\mathrm{~d}, J=7.9 \mathrm{~Hz}, 2 \mathrm{H})$, $7.37(\mathrm{~s}, 1 \mathrm{H}), 7.92(\mathrm{~d}, J=7.4 \mathrm{~Hz}, 2 \mathrm{H}) ;{ }^{13} \mathrm{C} \mathrm{NMR}\left(75 \mathrm{MHz}, \mathrm{CDCl}_{3}\right) \delta$ : 16.7, 18.8, 21.3, 21.6, 25.5, 25.6, 36.8, 37.6, 38.7, 45.4, 47.9, 52.1, 56.5, 61.1, 106.2, 119.0, 119.7, 126.8, 127.0, 128.6, 128.8, 129.8, $132.2,137.8,140.0,140.5,144.6,151.3,153.6,179.2$; IR $\left(\mathrm{KBr}, \mathrm{cm}^{-1}\right): 3330,2925,2854,1725,1666,1581,1497,1459$,
1382, 1245, 1186, 1127, 1021, 826, 731; MS (ESI): $\mathrm{m} / z$ 569.3 [M + $\mathrm{H}]^{+}$; anal. calcd for $\mathrm{C}_{35} \mathrm{H}_{40} \mathrm{~N}_{2} \mathrm{O}_{5}$ : C 73.92; $\mathrm{H}$ 7.09; $\mathrm{N}$ 4.93; found: C 73.87; H 7.13, N 4.99.

Methyl 2'-(4-fluorophenyl)-12-(3,4,5-trimethoxyphenyl)13,14-imidazolyl-deisopropyl-dehydroabietate (7c). White powder solid; mp $139-141{ }^{\circ} \mathrm{C}$; yield: $50.1 \%$; ${ }^{1} \mathrm{H}$ NMR $(500 \mathrm{MHz}$, $\left.\mathrm{CDCl}_{3}\right) \delta: 1.26(\mathrm{~s}, 3 \mathrm{H}), 1.34(\mathrm{~s}, 3 \mathrm{H}), 1.60-1.85(\mathrm{~m}, 7 \mathrm{H}), 2.01(\mathrm{~m}$, $1 \mathrm{H}), 2.41(\mathrm{~d}, J=12.3 \mathrm{~Hz}, 1 \mathrm{H}), 2.46$ (d, $J=13.7 \mathrm{~Hz}, 1 \mathrm{H}), 3.17$ (brs, $1 \mathrm{H}), 3.26$ (brs, $1 \mathrm{H}), 3.70(\mathrm{~s}, 3 \mathrm{H}), 3.92(\mathrm{~s}, 3 \mathrm{H}), 3.95(\mathrm{~s}, 6 \mathrm{H}), 6.84(\mathrm{~s}$, $2 \mathrm{H}), 7.16(\mathrm{t}, J=8.3 \mathrm{~Hz}, 2 \mathrm{H}), 7.36(\mathrm{~s}, 1 \mathrm{H}), 8.03(\mathrm{brs}, 2 \mathrm{H}) ;{ }^{13} \mathrm{C} \mathrm{NMR}$ $\left(75 \mathrm{MHz}, \mathrm{CDCl}_{3}\right) \delta: 16.7,18.8,21.3,25.5,25.6,36.9,37.6,38.7$, 45.5, 48.0, 52.1, 56.5, 61.1, 106.3, 116.2 (d, $J=21.9 \mathrm{~Hz}), 119.2$, 119.3, 123.6, 124.1, 124.5, 124.6, 128.6 (d, $J=8.5 \mathrm{~Hz}$ ), 137.7, 140.1, 147.3, 153.6, 154.4, 164.0 (d, $J=249.8 \mathrm{~Hz}), 179.3$; IR $\left(\mathrm{KBr}, \mathrm{cm}^{-1}\right): 3308,2959,2925,2855,1726,1598,1579,1493$, 1433, 1387, 1245, 1158, 1128, 1021, 843, 735; MS (ESI): $\mathrm{m} / z$ 573.3 $[\mathrm{M}+\mathrm{H}]^{+}$; anal. calcd for $\mathrm{C}_{34} \mathrm{H}_{37} \mathrm{FN}_{2} \mathrm{O}_{5}$ : C 71.31; $\mathrm{H} 6.51 ; \mathrm{N} 4.89$; found: C 71.38; $\mathrm{H}$ 6.48, N 4.83.

Methyl 2'-(3-fluorophenyl)-12-(3,4,5-trimethoxyphenyl)13,14-imidazolyl-deisopropyl-dehydroabietate (7d). Yellow powder solid; mp $156-158{ }^{\circ} \mathrm{C}$; yield: $72.9 \%$; ${ }^{1} \mathrm{H}$ NMR $(300 \mathrm{MHz}$, $\left.\mathrm{CDCl}_{3}\right) \delta: 1.26(\mathrm{~s}, 3 \mathrm{H}), 1.35(\mathrm{~s}, 3 \mathrm{H}), 1.50-1.90(\mathrm{~m}, 7 \mathrm{H}), 2.00(\mathrm{~m}$, $1 \mathrm{H}), 2.42$ (d, $J=12.5 \mathrm{~Hz}, 1 \mathrm{H}), 2.49(\mathrm{~m}, 1 \mathrm{H}), 3.10(\mathrm{~m}, 1 \mathrm{H}), 3.22$ (m, 1H), $3.70(\mathrm{~s}, 3 \mathrm{H}), 3.92(\mathrm{~s}, 3 \mathrm{H}), 3.95(\mathrm{~s}, 6 \mathrm{H}), 6.82(\mathrm{~s}, 2 \mathrm{H}), 7.14$ $(\mathrm{t}, J=7.6 \mathrm{~Hz}, 1 \mathrm{H}), 7.35(\mathrm{~s}, 1 \mathrm{H}), 7.45(\mathrm{~m}, 1 \mathrm{H}), 7.77(\mathrm{~d}, J=8.3 \mathrm{~Hz}$, $2 \mathrm{H}) ;{ }^{13} \mathrm{C} \mathrm{NMR}\left(125 \mathrm{MHz}, \mathrm{CDCl}_{3}\right) \delta: 16.7,18.8,21.3,25.4,25.6$, 36.9, 37.7, 38.6, 45.5, 48.0, 52.2, 56.5, 61.1, 106.3, 113.8 (d, $J=$ $23.5 \mathrm{~Hz}), 116.9$ (d, $J=20.9 \mathrm{~Hz}), 119.2,119.5,122.2,124.6,130.7$ $(\mathrm{d}, J=8.2 \mathrm{~Hz}), 132.5$ (d, $J=8.4 \mathrm{~Hz}), 134.7,136.7,137.9,139.6$, 144.9, 149.9, 153.6, 163.2 (d, $J=245.2 \mathrm{~Hz}), 179.4$; IR (KBr, $\left.\mathrm{cm}^{-1}\right)$ : 3305, 2928, 2854, 1724, 1659, 1582, 1492, 1462, 1243, 1126, 1006, 790, 760; MS (ESI): $m / z 573.3[\mathrm{M}+\mathrm{H}]^{+}$; anal. calcd for $\mathrm{C}_{34} \mathrm{H}_{37} \mathrm{FN}_{2} \mathrm{O}_{5}$ : C 71.31; $\mathrm{H} \mathrm{6.51;} \mathrm{N} 4.89$; found: $\mathrm{C} 71.22 ; \mathrm{H} \mathrm{6.57,} \mathrm{N}$ 4.92.

Methyl 2'-(2-fluorophenyl)-12-(3,4,5-trimethoxyphenyl)13,14-imidazolyl-deisopropyl-dehydroabietate (7e). Yellow powder solid; mp $155-157{ }^{\circ} \mathrm{C}$; yield: $53.1 \%$; ${ }^{1} \mathrm{H}$ NMR $(300 \mathrm{MHz}$, $\left.\mathrm{CDCl}_{3}\right) \delta: 1.35(\mathrm{~s}, 6 \mathrm{H}), 1.51-1.90(\mathrm{~m}, 7 \mathrm{H}), 2.01(\mathrm{~m}, 1 \mathrm{H}), 2.42(\mathrm{~d}, J$ $=11.7 \mathrm{~Hz}, 1 \mathrm{H}), 2.48(\mathrm{~m}, 1 \mathrm{H}), 3.07(\mathrm{brs}, 1 \mathrm{H}), 3.30(\mathrm{~m}, 1 \mathrm{H}), 3.69(\mathrm{~s}$, $3 \mathrm{H}), 3.95$ (s, 6H), 3.99 (s, 3H), $6.84(\mathrm{~s}, 2 \mathrm{H}), 7.20(\mathrm{~m}, 1 \mathrm{H}), 7.31-$ $7.43(\mathrm{~m}, 4 \mathrm{H}) ;{ }^{13} \mathrm{C}$ NMR (75 MHz, $\left.\mathrm{CDCl}_{3}\right) \delta: 16.7,18.8,21.3,25.4$, 25.5, 36.8, 37.7, 38.7, 45.5, 48.0, 52.1, 56.5, 61.1, 107.5, 116.2 (d, $J$ $=22.8 \mathrm{~Hz}$ ), $117.8(\mathrm{~d}, J=9.9 \mathrm{~Hz}), 118.6,119.5,123.4(\mathrm{~d}, J=24.9$ $\mathrm{Hz}), 125.3,130.4,131.4(\mathrm{~d}, J=6.8 \mathrm{~Hz}), 134.7,137.8,136.6,140.0$, 146.6, 152.8, 153.9, 160.4 (d, $J=245.0 \mathrm{~Hz}), 179.2$; IR ( $\left.\mathrm{KBr}, \mathrm{cm}^{-1}\right)$ : 3353, 2928, 2867, 2280, 1723, 1581, 1494, 1464, 1245, 1178, 1065, 1015, 824, 761. MS (ESI): $m / z 573.3[\mathrm{M}+\mathrm{H}]^{+}$; anal. calcd for $\mathrm{C}_{34} \mathrm{H}_{37} \mathrm{FN}_{2} \mathrm{O}_{5}$ : C 71.31; $\mathrm{H} 6.51 ; \mathrm{N} 4.89$; found: $\mathrm{C} 71.36 ; \mathrm{H} \mathrm{6.59,} \mathrm{N}$ 4.81 .

Methyl 2'-(4-chlorophenyl)-12-(3,4,5-trimethoxyphenyl)13,14-imidazolyl-deisopropyl-dehydroabietate (7f). Yellow powder solid; mp $168-170{ }^{\circ} \mathrm{C}$; yield: $59.9 \%$; ${ }^{1} \mathrm{H}$ NMR $(300 \mathrm{MHz}$, $\left.\mathrm{CDCl}_{3}\right) \delta: 1.26(\mathrm{~s}, 3 \mathrm{H}), 1.35(\mathrm{~s}, 3 \mathrm{H}), 1.50-1.85(\mathrm{~m}, 7 \mathrm{H}), 1.99(\mathrm{~m}$, $1 \mathrm{H}), 2.41$ (d, $J=12.5 \mathrm{~Hz}, 1 \mathrm{H}), 2.48(\mathrm{~m}, 1 \mathrm{H}), 3.16$ (brs, 1H), 3,23 (brs, 1H), 3.69 (s, 3H), $3.92(\mathrm{~s}, 3 \mathrm{H}), 3.95(\mathrm{~s}, 6 \mathrm{H}), 6.82(\mathrm{~s}, 2 \mathrm{H}), 7.35$ $(\mathrm{s}, 1 \mathrm{H}), 7.46(\mathrm{~d}, J=8.4 \mathrm{~Hz}, 2 \mathrm{H}), 7.97(\mathrm{~d}, J=7.7 \mathrm{~Hz}, 2 \mathrm{H}) ;{ }^{13} \mathrm{C} \mathrm{NMR}$ $\left(75 \mathrm{MHz}, \mathrm{CDCl}_{3}\right.$ ) $\delta: 16.7,18.8,21.3,25.4,25.6,36.9,37.6,38.6$, 
45.5, 48.0, 52.2, 56.5, 61.1, 106.3, 119.0, 119.2, 124.5, 127.9, $128.8,129.3$, 134.8, 136.0, 137.8, 139.0, 140.8, 141.3, 150.1, 153.6, 179.4; IR (KBr, cm $\left.{ }^{-1}\right): 3317,2926,2853,1725,1581,1495$, 1461, 1428, 1381, 1244, 1127, 1014, 836, 730. MS (ESI): $m / z 589.2$ $[\mathrm{M}+\mathrm{H}]^{+}$; anal. calcd (\%) for $\mathrm{C}_{34} \mathrm{H}_{37} \mathrm{ClN}_{2} \mathrm{O}_{5}$ : C, 69.32; H, 6.33; N, 4.76; found (\%): C, 69.38; H, 6.25; N, 4.82 .

Methyl 2'-(2-chlorophenyl)-12-(3,4,5-trimethoxyphenyl)13,14-imidazolyl-deisopropyl-dehydroabietate (7g). Yellow powder solid; mp 157-159 ${ }^{\circ} \mathrm{C}$; yield: $72.4 \%$; ${ }^{1} \mathrm{H}$ NMR $(300 \mathrm{MHz}$, $\left.\mathrm{CDCl}_{3}\right) \delta: 1.26(\mathrm{~s}, 3 \mathrm{H}), 1.35(\mathrm{~s}, 3 \mathrm{H}), 1.50-2.10(\mathrm{~m}, 7 \mathrm{H}), 2.42(\mathrm{~d}, J=$ $11.7 \mathrm{~Hz}, 1 \mathrm{H}), 2.48(\mathrm{~m}, 1 \mathrm{H}), 3.06$ (brs, $1 \mathrm{H}), 3.31(\mathrm{~m}, 1 \mathrm{H}), 3.50(\mathrm{~m}$, $1 \mathrm{H}), 3.69(\mathrm{~s}, 3 \mathrm{H}), 3.93(\mathrm{~s}, 3 \mathrm{H}), 3.96(\mathrm{~s}, 6 \mathrm{H}), 6.85(\mathrm{~s}, 2 \mathrm{H}), 7.35-7.43$ (m, 3H), 7.48 (d, $J=7.6 \mathrm{~Hz}, 1 \mathrm{H}), 8.44$ (brs, $1 \mathrm{H}) ;{ }^{13} \mathrm{C} \mathrm{NMR}(75$ $\mathrm{MHz} \mathrm{CDCl}_{3}$ ) $\delta: 16.7,18.8,21.3,25.4,25.6,36.8,37.7,38.8,45.5$, $48.0,52.1,56.4,61.1,106.9,119.5,119.7,126.7,127.7,128.8$, $129.5,130.0,130.7,132.4,133.2,137.8,139.5,140.3,146.1$, 148.5, 153.4, 179.2; IR (KBr, $\left.\mathrm{cm}^{-1}\right): 3355,2924,2852,1724,1666$, $1577,1494,1454,1244,1126,1046,1016,764,732$. MS (ESI): $m / z$ $589.2[\mathrm{M}+\mathrm{H}]^{+}$; anal. calcd (\%) for $\mathrm{C}_{34} \mathrm{H}_{37} \mathrm{ClN}_{2} \mathrm{O}_{5}$ : C, 69.32; $\mathrm{H}$, 6.33; N, 4.76; found (\%): C, 69.26; H, 6.37; N, 4.71.

Methyl 2'-(4-bromophenyl)-12-(3,4,5-trimethoxyphenyl)13,14-imidazolyl-deisopropyl-dehydroabietate (7h). Yellow powder solid; mp 150-152 ${ }^{\circ} \mathrm{C}$; yield: $54.1 \%$; ${ }^{1} \mathrm{HNMR}(300 \mathrm{MHz}$, $\left.\mathrm{CDCl}_{3}\right) \delta: 1.26(\mathrm{~s}, 3 \mathrm{H}), 1.35(\mathrm{~s}, 3 \mathrm{H}), 1.50-1.90(\mathrm{~m}, 7 \mathrm{H}), 2.00(\mathrm{~m}$, $1 \mathrm{H}), 2.42$ (d, $J=11.8 \mathrm{~Hz}, 1 \mathrm{H}), 2.48(\mathrm{~m}, 1 \mathrm{H}), 3.08$ (brs, 1H), 3.28 (brs, 1H), 3.69 (s, 3H), $3.92(\mathrm{~s}, 3 \mathrm{H}), 3.95(\mathrm{~s}, 6 \mathrm{H}), 6.82(\mathrm{~s}, 2 \mathrm{H}), 7.36$ $(\mathrm{s}, 1 \mathrm{H}), 7.67(\mathrm{~d}, J=8.2 \mathrm{~Hz}, 2 \mathrm{H}), 8.10(\mathrm{~d}, J=9.3 \mathrm{~Hz}, 2 \mathrm{H}) ;{ }^{13} \mathrm{C} \mathrm{NMR}$ $\left(75 \mathrm{MHz}, \mathrm{CDCl}_{3}\right.$ ) $\delta: 16.7,18.8,21.3,25.4,25.6,36.8,37.6,38.6$, 45.5 , 48.0, 52.1, 56.4, 61.1, 104.7, 118.4, 119.7, 127.0, 127.6, $129.0,129.2,131.0,136.2,137.8,138.4,142.8,144.5,150.9$, 153.8, 179.3; IR (KBr, $\left.\mathrm{cm}^{-1}\right)$ : 3285, 2928, 2854, 1724, 1584, 1459, 1343, 1245, 1188, 1093, 1008, 878, 825, 745. MS (ESI): $m / z$ 632.2, $634.2[\mathrm{M}+\mathrm{H}]^{+}$; anal. calcd (\%) for $\mathrm{C}_{34} \mathrm{H}_{37} \mathrm{BrN}_{2} \mathrm{O}_{5}$ : C, 64.45; $\mathrm{H}$, 5.89; N, 4.42; found (\%): C, 64.36; H, 5.92; N, 4.38.

Methyl 2'-(4-methoxyphenyl)-12-(3,4,5-trimethoxyphenyl)13,14-imidazolyl-deisopropyl-dehydroabietate (7i). White powder solid; mp 153-155 ${ }^{\circ} \mathrm{C}$; yield: $70.7 \%$; ${ }^{1} \mathrm{H}$ NMR $(500 \mathrm{MHz}$, $\left.\mathrm{CDCl}_{3}\right) \delta: 1.26(\mathrm{~s}, 3 \mathrm{H}), 1.34(\mathrm{~s}, 3 \mathrm{H}), 1.50-1.84(\mathrm{~m}, 7 \mathrm{H}), 2.01(\mathrm{~m}$, $1 \mathrm{H}), 2.40$ (d, $J=12.2 \mathrm{~Hz}, 2 \mathrm{H}), 2.46$ (brs, $1 \mathrm{H}), 3.30(\mathrm{~m}, 1 \mathrm{H}), 3.69$ (s, 3H), $3.87(\mathrm{~s}, 3 \mathrm{H}), 3.92(\mathrm{~s}, 6 \mathrm{H}), 3.95(\mathrm{~s}, 3 \mathrm{H}), 6.80(\mathrm{~s}, 2 \mathrm{H}), 7.00$ $(\mathrm{d}, J=8.2 \mathrm{~Hz}, 2 \mathrm{H}), 7.35(\mathrm{~s}, 1 \mathrm{H}), 7.96(\mathrm{~d}, J=8.2 \mathrm{~Hz}, 2 \mathrm{H}) ;{ }^{13} \mathrm{C} \mathrm{NMR}$ $\left(75 \mathrm{MHz}, \mathrm{CDCl}_{3}\right.$ ) $\delta: 16.7,18.8,21.3,25.5,25.6,36.8,37.6,38.7$, 45.5, 48.0, 52.1, 55.6, 56.5, 61.1, 107.3, 113.9, 114.2, 114.5, 119.7, $121.5,126.4$, 128.1, 131.0, 136.7, 138.6, 140.6, 151.4, 153.2, 162.9, 179.3; IR (KBr, cm $\left.{ }^{-1}\right): 3330,2925,2854,1725,1666,1581$, 1497, 1459, 1382, 1245, 1186, 1127, 1021, 826, 731; MS (ESI): $\mathrm{m} / z$ $584.3[\mathrm{M}+\mathrm{H}]^{+}$; anal. calcd for $\mathrm{C}_{35} \mathrm{H}_{40} \mathrm{~N}_{2} \mathrm{O}_{6}$ : C 71.90; $\mathrm{H} \mathrm{6.90;} \mathrm{N}$ 4.79; found: C 71.87; $\mathrm{H} 6.92, \mathrm{~N} 4.81$.

Methyl 2'-(1H-indol-5-yl)-12-(3,4,5-trimethoxyphenyl)-13,14imidazolyl-deisopropyl-dehydroabietate (7j). White powder solid; mp 189-191 ${ }^{\circ} \mathrm{C}$; yield: $61.8 \% ;{ }^{1} \mathrm{H}$ NMR (300 $\mathrm{MHz}, \mathrm{CDCl}_{3}$ ) $\delta: 1.26(\mathrm{~s}, 3 \mathrm{H}), 1.35(\mathrm{~s}, 3 \mathrm{H}), 1.50-1.80(\mathrm{~m}, 7 \mathrm{H}), 2.02(\mathrm{~m}, 1 \mathrm{H}), 2.43$ $(\mathrm{d}, J=12.1 \mathrm{~Hz}, 1 \mathrm{H}), 2.47(\mathrm{~d}, J=12.2 \mathrm{~Hz}, 1 \mathrm{H}), 3.21$ (brs, 2H), 3.70 (s, 3H), $3.93(\mathrm{~s}, 3 \mathrm{H}), 3.96(\mathrm{~s}, 6 \mathrm{H}), 6.62(\mathrm{~s}, 1 \mathrm{H}), 6.82(\mathrm{~s}, 2 \mathrm{H}), 7.25(\mathrm{~s}$, $1 \mathrm{H}), 7.31(\mathrm{~s}, 1 \mathrm{H}), 7.46(\mathrm{~d}, J=8.5 \mathrm{~Hz}, 1 \mathrm{H}), 7.91(\mathrm{~d}, J=8.3 \mathrm{~Hz}, 1 \mathrm{H})$, 8.26 (s, $1 \mathrm{H}), 8.47$ (brs, $1 \mathrm{H}) ;{ }^{13} \mathrm{C} \mathrm{NMR}\left(75 \mathrm{MHz} \mathrm{CDCl}_{3}\right) \delta: 16.7$, 18.8, 21.3, 25.5, 25.6, 36.9, 37.6, 38.7, 45.5, 48.0, 52.1, 56.5, 61.1,
$103.2,106.3,111.8,118.4,119.3,119.7,121.1,122.0,125.8$, 128.2 , 129.0, 131.0, 135.2, 137.0, 137.7, 140.9, 144.1, 153.2, 153.6, 179.4; IR (KBr, cm $\left.{ }^{-1}\right): 3345,2959,2924,2853,1724,1620$, 1580, 1498, 1456, 1379, 1258, 1126, 836, 737; MS (ESI): $m / z 593.3$ $[\mathrm{M}+\mathrm{H}]^{+}$; anal. calcd for $\mathrm{C}_{36} \mathrm{H}_{39} \mathrm{~N}_{2} \mathrm{O}_{5}$ : C 72.83; H 6.62; N 7.08; found: C 72.85; $\mathrm{H}$ 6.62, N 7.05.

Methyl 2 '-(1H-indol-3-yl)-12-(3,4,5-trimethoxyphenyl)-13,14imidazolyl-deisopropyl-dehydroabietate (7k). White powder solid; mp 199-201 ${ }^{\circ} \mathrm{C}$; yield: $56.2 \%$; ${ }^{1} \mathrm{H}$ NMR (500 MHz, $\mathrm{CDCl}_{3}$ ) $\delta: 1.27(\mathrm{~s}, 3 \mathrm{H}), 1.33(\mathrm{~s}, 3 \mathrm{H}), 1.50-1.80(\mathrm{~m}, 7 \mathrm{H}), 1.98(\mathrm{~m}, 1 \mathrm{H}), 2.38$ $(\mathrm{d}, J=12.2 \mathrm{~Hz}, 1 \mathrm{H}), 2.46(\mathrm{~d}, J=12.0 \mathrm{~Hz}, 1 \mathrm{H}), 3.11(\mathrm{~m}, 1 \mathrm{H}), 3.21$ $(\mathrm{m}, 1 \mathrm{H}), 3.66(\mathrm{~s}, 3 \mathrm{H}), 3.89(\mathrm{~s}, 3 \mathrm{H}), 3.93(\mathrm{~s}, 6 \mathrm{H}), 7.06-7.22(\mathrm{~m}, 5 \mathrm{H})$, 7.25 (s, 1H), 7.67 (s, 1H), 8.21 (s, 1H), 9.59 (brs, $1 \mathrm{H}) ;{ }^{13} \mathrm{C}$ NMR (75 $\left.\mathrm{MHz} \mathrm{CDCl}_{3}\right) \delta: 16.7,18.8,21.4,25.5,25.7,36.9,37.6,38.7,45.4$, 48.0, 52.1, 56.4, 61.1, 106.1, 106.2, 112.0, 118.2, 120.3, 120.4, 121.3 , 123.1, 125.4, 126.1, 127.0, 131.1, 135.3, 136.6, 137.7, 139.9, 144.2, 148.9, 153.6, 179.4; IR (KBr, $\left.\mathrm{cm}^{-1}\right)$ : 3398, 3058, 2926, 2853, 1725, 1624, 1584, 1498, 1455, 1427, 1377, 1295, 1125, 833, 743; MS (ESI): $m / z 593.3[\mathrm{M}+\mathrm{H}]^{+}$; anal. calcd for $\mathrm{C}_{36} \mathrm{H}_{39} \mathrm{~N}_{2} \mathrm{O}_{5}$ : C 72.83; $\mathrm{H} \mathrm{6.62;} \mathrm{N} \mathrm{7.08;} \mathrm{found:} \mathrm{C} 72.80 ; \mathrm{H} \mathrm{6.63,} \mathrm{N}$ 7.09 .

\section{Cell lines and culture}

The human hepatocarcinoma cell line (SMMC-7721), human breast cancer cell line (MDA-MB-231), human cervical carcinoma cell line (HeLa), mouse colon cancer cell line (CT-26) and human normal hepatocyte cells (QSG-7701) used in this study were all obtained from Keygene Biotech., China. These cell lines were maintained in DMEM medium supplemented with 10\% heat-inactivated fetal bovine serum in a humidified atmosphere of $5 \% \mathrm{CO}_{2}$ at $37{ }^{\circ} \mathrm{C}$.

\section{Cytotoxic assay}

The in vitro cytotoxic activities of the benzimidazole derivatives of dehydroabietic acid were evaluated against tested cell lines via the MTT colorimetric method. Briefly, different tumor cells were grown in DMEM medium supplemented with $10 \%$ fetal bovine serum, penicillin (100 $\left.\mathrm{U} \mathrm{mL}^{-1}\right)$, and streptomycin $(50 \mu \mathrm{g}$ $\left.\mathrm{mL}^{-1}\right)$. Cells were harvested at log phase of growth and seeded in 96-well plates $\left(100 \mu \mathrm{L}\right.$ per well at a density of $2 \times 10^{5}$ cells $\mathrm{mL}^{-1}$ ). After $24 \mathrm{~h}$ incubation at $37{ }^{\circ} \mathrm{C}$ and $5 \% \mathrm{CO}_{2}$ to allow cell attachment, cultures were exposed to various concentrations of the isolated compounds for $48 \mathrm{~h}$. Finally, MTT solution $(2.5 \mathrm{mg}$ $\mathrm{mL}^{-1}$ in PBS) was added ( $40 \mu \mathrm{L}$ per well). Plates were further incubated for $4 \mathrm{~h}$ at $37{ }^{\circ} \mathrm{C}$, and the formazan crystals formed were dissolved by adding $150 \mu \mathrm{L}$ per well of DMSO. Absorption at $570 \mathrm{~nm}$ was measured with an ELISA plate reader. The results were expressed as $\mathrm{IC}_{50}$ values with standard deviations, which was defined as the concentration at which $50 \%$ survival of cells was discerned. Nocodazole was co-assayed as positive control.

\section{In vitro tubulin polymerization inhibition}

The tubulin polymerization assay was accomplished using a commercial assay kit (cat. \#BK004P) purchased from Cytoskeleton, Inc. (Danvers, MA, USA). Tubulin isolated from porcine brain tissue was used in this tubulin polymerization 
assay kit. Tubulin polymerizations are followed by an increase in optical density at $340 \mathrm{~nm}\left(\mathrm{OD}_{340}\right)$ over a $60 \mathrm{~min}$ period at $37{ }^{\circ} \mathrm{C}$ due to the light scattered by microtubule polymer. At first, tubulin ( $4 \mathrm{mg}$ ) was disovled in $1 \mathrm{~mL}$ of G-PEM buffer containing $80 \mathrm{mM}$ piperazine- $N, N^{\prime}$-bis(2-ethanesulfonic acid) sequisodium salt (PIPES, pH 6.9), $2.0 \mathrm{mM} \mathrm{MgCl}_{2}, 0.5 \mathrm{mM}$ EGTA and $1 \mathrm{mM}$ GTP to prepare tubulin solution. Subsequently, $10 \mu \mathrm{L}$ of $10 \times$ stock solutions of the tested compounds at different concentrations were added to a prewarmed 96-well plate and incubated at $37^{\circ} \mathrm{C}$ for $2 \mathrm{~min}$, then $90 \mu \mathrm{L}$ of tubulin solution was also added into each well to initiate the reaction. The optical intensity $\left(\mathrm{OD}_{340}\right)$ of each well was recorded every $60 \mathrm{~s}$ for $60 \mathrm{~min}$ (Cytation 3 Cell Imaging Multi-Mode Reader, BioTek Instruments, Inc., USA). Colchicine and taxol were co-assayed as the positive control and negative control, respectively. G-PEM buffer was used as the blank control.

\section{Immunofluorescence}

The intracellular microtubule morphology was investigated using the protocol previously reported. ${ }^{52}$ For the immunofluorescence studies, SMMC-7721 cells $\left(3 \times 10^{5}\right.$ cells per well) were seeded on $10 \mathrm{~mm}^{2}$ confocal culture dishes (NEST Biotechnology, China) for $24 \mathrm{~h}$ and then incubated in the absence or presence of compound $\mathbf{6 j}$ at the indicated concentrations for another $12 \mathrm{~h}$. After being washed with phosphate buffer solution (PBS) and fixed in 4\% paraformaldehyde for $15 \mathrm{~min}$, the cells were permeabilized with $0.5 \%$ Triton X-100 for $15 \mathrm{~min}$ and blocked for $30 \mathrm{~min}$ with $10 \%$ goat serum. Then, the cells were incubated with mouse anti-tubulin antibody (ZSGB-Bio, China) at $4{ }^{\circ} \mathrm{C}$ overnight and incubated with goat anti-mouse IgG/AlexaFluor 488 antibody (ZSGB-Bio, China) at room temperature for $1 \mathrm{~h}$. After the nuclei were stained with Hoechst 33258 (Beyotime Biotech., China) in the dark at room temperature for $30 \mathrm{~min}$, the samples were immediately visualized on a Zeiss LSM 570 laser scanning confocal microscope (Carl Zeiss, Germany).

\section{Wound healing assay}

SMMC-7721 cells $\left(5 \times 10^{5}\right.$ cells per well) were grown in a 12-well plate for $24 \mathrm{~h}$. Scratches were made in confluent monolayers using $200 \mu \mathrm{L}$ pipette tip. Then, wounds were washed twice with PBS to remove non-adherent cell debris. The media containing different concentrations $(0,0.1,0.2$ and $0.5 \mu \mathrm{M})$ of compound $\mathbf{6 j}$ were added to the corresponding wells. Cells which migrated across the wound area were photographed under the phase contrast microscope (Olympus 1X71 Inverted System Microscope, Olympus, Japan) after 24 and $48 \mathrm{~h}$ treatment.

\section{Cell cycle analysis}

For the flow cytometric analysis of the DNA content, SMMC7721 cells were seeded in 6 -well plates $\left(5 \times 10^{5}\right.$ cells per well $)$ and incubated in the absence or presence of compound $\mathbf{6 j}$ at indicated concentrations for $24 \mathrm{~h}$. After treatment, cells were detached with $0.25 \%$ trypsin, harvested by centrifugation, washed twice with ice-cold PBS and then fixed and permeabilized with ice-cold ethanol at $4{ }^{\circ} \mathrm{C}$ overnight. Ethanol was removed by centrifugation, and the cells were washed twice and resuspended in ice-cold PBS. After this, the cells were treated with $100 \mu \mathrm{L}$ of $100 \mu \mathrm{g} \mathrm{mL}{ }^{-1}$ RNAse A at $37{ }^{\circ} \mathrm{C}$ for $30 \mathrm{~min}$, followed by incubation with $400 \mu \mathrm{L}$ of $1 \mathrm{mg} \mathrm{mL}^{-1}$ DNA staining solution propidium iodide (PI) in the dark at $4{ }^{\circ} \mathrm{C}$ for $30 \mathrm{~min}$. The samples were then analyzed for their DNA content by flow cytometry (Becton-Dickinson FACSCalibur, New York, USA).

\section{Annexin V-FITC/PI dual staining assay}

Apoptosis was discriminated with the Annexin V-FITC/PI dual staining assay. SMMC-7721 cells were seeded at $1 \times 10^{5}$ cells per well in $10 \%$ fetal calf serum (FBS)-DMEM into six-well plates and treated with or without compound $\mathbf{6 j}$ for $24 \mathrm{~h}$. The cells were detached with $0.25 \%$ trypsin, washed twice with ice-cold PBS and then resuspended in $500 \mu \mathrm{L}$ of $1 \times$ binding buffer (0.1 M Hepes/NaOH (pH 7.4), 1.4 M NaCl, $25 \mathrm{mM} \mathrm{CaCl}_{2}$ ). The solution was transferred into $5 \mathrm{~mL}$ culture tubes, and $5 \mu \mathrm{L}$ of Annexin V-FITC (BD, Pharmingen) and $5 \mu \mathrm{L}$ of PI were added to each tube. The cells were gently vortexed, and incubated for $30 \mathrm{~min}$ at $25{ }^{\circ} \mathrm{C}$ in the dark. The analysis was performed on a flow cytometry (Becton-Dickinson FACSCalibur, New York, USA).

\section{ROS generation assay}

ROS generation assay was performed by using the reactive oxygen species assay kit (Beyotime Biotech., China). Intracellular ROS generation was tested through dichlorodihydro fluorescein diacetate (DCFH-DA) assay. DCFH-DA is taken up by SMMC-7721 cells, and then activated by esterase-mediated cleavage of acetate to form dichlorodihydro fluorescein (DCFH), which is trapped in the cells. DCFH is converted to fluorescein DCF in the presence of ROS. SMMC-7721 cells were seeded in six-well plates and incubated with different concentrations of compound $\mathbf{6 j}$ for $24 \mathrm{~h}$. After removing the compound solution, cells were treated with $10 \mu \mathrm{M}$ of DCFH-DA at $37^{\circ} \mathrm{C}$ for $20 \mathrm{~min}$. Subsequently, the cells were washed with PBS for three times and then exposed to light. Immediately after light exposure, cell images were acquired through an inverted fluorescence microscope (Olympus 1X71 Inverted System Microscope, Olympus, Japan).

\section{JC-1 mitochondrial membrane potential assay}

The JC-1 mitochondrial membrane potential assay kit (Keygene Biotech., China) was employed to measure mitochondrial depolarization in SMMC-7721 cells. Briefly, cells cultured in sixwell plates after indicated treatments were incubated with an equal volume of JC-1 staining solution $\left(5 \mu \mathrm{g} \mathrm{mL}{ }^{-1}\right)$ at $37^{\circ} \mathrm{C}$ for $20 \mathrm{~min}$ and rinsed twice with PBS. Mitochondrial membrane potentials were monitored by determining the relative amounts of dual emissions from mitochondrial JC-1 monomers or aggregates using flow cytometry (Becton-Dickinson FACSCalibur, New York, USA). Mitochondrial depolarization is indicated by an increase in the percentage of cells with low $\Delta \Psi_{\mathrm{m}}$ (green fluorescence, lower right quadrant) compared with cells with high $\Delta \Psi_{\mathrm{m}}$ (red fluorescence, upper right quadrant). 


\section{Molecular modelling}

$\mathrm{X}$-ray structures of the tubulin co-crystal was retrieved from the PDB (accession code: 1SA0) ${ }^{53}$ and prepared using the Protein Preparation Wizard workflow from Schrödinger suite, ${ }^{50}$ including optimization of the hydrogen bond network and a short energy minimization with position restraints on heavy atoms using the OPLS_2005 force field. Ligands were then freely docked in the colchicine binding site located between chains A and B using the standard protocol implemented in Maestro, version 10.1. van der Waals (vdW) scaling of 0.8 and partial cutoff of 0.15 were set to soften the potential for non-polar sites, and no constraints were specified. The best docked pose ranked by GlideScore value was recorded, and saved for each ligand. The structures of complexes were analysed for interactions and the $3 \mathrm{D}$ pose of the most active compound $\mathbf{6 j}$ was displayed using Discovery studio 3.5 client.

\section{Conflicts of interest}

There are no conflicts to declare.

\section{Acknowledgements}

This work was supported by the National Natural Science Foundation of China (31770616), the Natural Science Foundation of Jiangsu Province (BK201516), the Natural Science Foundation for Colleges and Universities in Jiangsu Province (17KJA220002), Top-notch Academic Programs Project of Jiangsu Higher Education Institutions (PPZY2015C221) and a Project Funded by the Priority Academic Program Development of Jiangsu Higher Education Institutions (PAPD). The authors are grateful to the Advanced Analysis \& Testing Center of Nanjing Forestry University for the measurement of NMR data.

\section{Notes and references}

1 J. Seligmann and C. Twelves, Future Med. Chem., 2013, 5, 339-352.

2 X. C. Huang, R. Z. Huang, L. X. Li, S. H. Gou and H. S. Wang, Eur. J. Med. Chem., 2017, 132, 11-25.

3 N. G. Vindya, N. Sharma, M. Yadav and K. R. Ethiraj, Curr. Top. Med. Chem., 2015, 15, 73-82.

4 M. S. Poruchynsky, E. Komlodi-Pasztor, S. Trostel, J. Wilkerson, M. Regairaz, Y. Pommier, X. Zhang, T. K. Maity, R. Robey, M. Burotto, D. Sackett, U. Guha and A. T. Fojo, Proc. Natl. Acad. Sci. U. S. A., 2015, 112, 1571-1576. 5 M. A. Jordan and L. Wilson, Nat. Rev. Cancer, 2004, 4, 253265.

6 A. E. Prota, K. Bargsten, D. Zurwerra, J. J. Field, J. F. Díaz, K.-H. Altmann and M. O. Steinmetz, Science, 2013, 339, 587-590.

7 Y. Lu, J. Chen, J. Wang, C.-M. Li, S. Ahn, C. M. Barrett, J. T. Dalton, W. Li and D. D. Miller, J. Med. Chem., 2014, 57, 7355-7366.
8 P. K. Sorger, M. Dobles, R. Tournebize and A. A. Hyman, Curr. Opin. Cell Biol., 1997, 9, 807-814.

9 Y. Lu, J. Chen, M. Xiao, W. Li and D. D. Miller, Pharm. Res., 2012, 29, 2943-2971.

10 M.-T. Cui, L. Jiang, M. Goto, P.-L. Hsu, L. Li, Q. Zhang, L. Wei, S.-J. Yuan, E. Hamel, S. L. Morris-Natschke, K.-H. Lee and L. Xie, J. Med. Chem., 2017, 60, 5586-5598.

11 G. F. Mangiatordi, D. Trisciuzzi, D. Alberga, N. Denora, R. M. Iacobazzi, D. Gadaleta, M. Catto and O. Nicolotti, Eur. J. Med. Chem., 2017, 139, 792-803.

12 G. R. Pettit, S. B. Singh, E. Hamel, C. M. Lin, D. S. Alberts and D. Garcia-Kendall, Experientia, 1989, 45, 209-211.

13 G. G. Dark, S. A. Hill, V. E. Prise, G. M. Tozer, G. R. Pettit and D. J. Chaplin, Cancer Res., 1997, 57, 1829-1834.

14 G. J. Rustin, S. M. Galbraith, H. Anderson, M. Stratford, L. K. Folkes, L. Sena, L. Gumbrell and P. M. Price, J. Clin. Oncol., 2003, 21, 2815-2822.

15 S. L. Young and D. J. Chaplin, Expert Opin. Invest. Drugs, 2004, 13, 1171-1182.

16 I. Khelifi, T. Naret, D. Renko, A. Hamze, G. Bernadat, J. Bignon, C. Lenoir, J. Dubois, J.-D. Brion, O. Provot and M. Alami, Eur. J. Med. Chem., 2017, 127, 1025-1034.

17 N. Shrivastava, M. J. Naim, M. J. Alam, F. Nawaz, S. Ahmed and O. Alam, Arch. Pharm., 2017, 350, e1700040.

18 A. Kamal, B. Nagaseshadri, V. L. Nayak, V. Srinivasulu, M. Sathish, J. S. Kapure and C. S. Reddy, Bioorg. Chem., 2015, 63, 72-84.

19 P. Singla, V. Luxami, R. Singh, V. Tandon and K. Paul, Eur. J. Med. Chem., 2017, 126, 24-35.

20 P. Purushottamachar, A. M. Godbole, L. K. Gediya, M. S. Martin, T. S. Vasaitis, A. K. Kwegyir-Afful, S. Ramalingam, Z. Ates-Alagoz and V. C. O. Njar, J. Med. Chem., 2013, 56, 4880-4898.

21 A. Temirak, Y. M. Shaker, F. A. F. Ragab, M. M. Ali, H. I. Ali and H. I. El Diwani, Eur. J. Med. Chem., 2014, 87, 868-880.

22 A. W. White, R. Almassy, A. H. Calvert, N. J. Curtin, R. J. Griffin, Z. Hostomsky, K. Maegley, D. R. Newell, S. Srinivasan and B. T. Golding, J. Med. Chem., 2000, 43, 4084-4097.

23 P. Singla, V. Luxami and K. Paul, Bioorg. Med. Chem., 2015, 23, 1691-1700.

24 W. Yan, X. Y. Wang, Y. Dai, B. Zhao, X. Y. Yang, J. Fan, Y. L. Gao, F. W. Meng, Y. M. Wang, C. Luo, J. Ai, M. Y. Geng and W. H. Duan, J. Med. Chem., 2016, 59, 6690-6708.

25 F. C. Torres, M. E. García-Rubiño, C. Lozano-López, D. F. Kawano, V. L. Eifler-Lima, G. L. von Poser and J. M. Campos, Curr. Med. Chem., 2015, 22, 1312-1323.

26 R. J. Vasquez, B. Howell, A. M. Yvon, P. Wadsworth and L. Cassimeris, Mol. Biol. Cell, 1997, 8, 973-985.

27 W. Shi and D. W. Siemann, Anticancer Res., 2005, 25, 38993904.

28 A. Rai, T. K. Gupta, S. Kini, A. Kunwar, A. Surolia and D. Panda, Biochem. Pharmacol., 2013, 86, 378-391.

29 A. Kamal, T. S. Reddy, M. V. P. S. Vishnuvardhan, V. D. Nimbarte, A. V. S. Rao, V. Srinivasulu and N. Shankaraiah, Bioorg. Med. Chem., 2015, 23, 4608-4623. 
30 C. Alvarez, R. Alvarez, P. Corchete, C. Perez-Melero, R. Pelaez and M. Medarde, Eur. J. Med. Chem., 2010, 45, 588-597.

31 D. J. Newman, G. M. Cragg and K. M. Snader, J. Nat. Prod., 2003, 66, 1022-1037.

32 W. M. Zhang, T. Yang, X. Y. Pan, X. L. Liu, H. X. Lin, Z. B. Gao, C. G. Yang and Y. M. Cui, Eur. J. Med. Chem., 2017, 127, 917-927.

33 M. W. Pertino, C. Vega, M. Rolón, C. Coronel, A. R. de Arias and G. Schmeda-Hirschmann, Molecules, 2017, 22, 369.

34 V. C. Roa-Linares, Y. M. Brand, L. S. Agudelo-Gomez, V. Tangarife-Castano, L. A. Betancur-Galvis, J. C. GallegoGomez and M. A. Gonzalez, Eur. J. Med. Chem., 2016, 108, 79-88.

35 H. Wada, S. Kodato, M. Kawamori, T. Morikawa, H. Nakai, M. Takeda, S. Saito, Y. Onoda and H. Tamaki, Chem. Pharm. Bull., 1985, 33, 1472-1487.

36 J. Kim, Y. G. Kang, J. S. Park, J. H. Lee, J. Y. Lee, J. M. Shin, D. H. Choi, Y. U. Cho, W. G. Kim, D. B. Seo, T. R. Lee, Y. Miyamoto and K. T. No, Mol. Cell. Endocrinol., 2015, 412, 216-225.

37 M. A. Esteves, N. Narender, M. J. Marcelo-Curto and B. Gigante, J. Nat. Prod., 2001, 64, 761-766.

38 B. L. Fei, W. S. Xu, W. L. Gao, J. Zhang, Y. Zhao, J. Y. Long, C. E. Anson and A. K. Powell, J. Photochem. Photobiol., B, 2015, 142, 77-85.

39 X. C. Huang, R. Z. Huang, Z. X. Liao, Y. M. Pan, S. H. Gou and H. S. Wang, Eur. J. Med. Chem., 2016, 108, 381-391.

40 D. J. Luo, Q. Ni, A. L. Ji, W. Gu, J. H. Wu and C. P. Jiang, BioMed Res. Int., 2016, 2016, 2581061.
41 R. Z. Huang, G. B. Liang, X. C. Huang, B. Zhang, M. M. Zhou, Z. X. Liao and H. S. Wang, Eur. J. Med. Chem., 2017, 138, 979992.

42 W. Gu, T. T. Miao, D. W. Hua, X. Y. Jin, X. B. Tao, C. B. Huang and S. F. Wang, Bioorg. Med. Chem. Lett., 2017, 27, 12961300.

43 W. Gu, S. Wang, X. Y. Jin, Y. L. Zhang, D. W. Hua, T. T. Miao, X. B. Tao and S. F. Wang, Molecules, 2017, 22, 1154.

44 T. Fonseca, B. Gigante, M. M. Marques, T. L. Gilchrist and E. De Clercq, Bioorg. Med. Chem., 2004, 12, 103-112.

45 S. D. Guggilapu, L. Guntuku, T. S. Reddy, A. Nagarsenkar, D. K. Sigalapalli, V. G. M. Naidu, S. K. Bhargava and N. B. Bathini, Eur. J. Med. Chem., 2017, 138, 83-95.

46 J.-C. Martinou and R. J. Youle, Dev. Cell, 2011, 21, 92-101.

47 M. L. Circu and T. Y. Aw, Free Radicals Biol. Med., 2010, 48, 749-762.

48 S. Orrenius, B. Zhivotovsky and P. Nicotera, Nat. Rev. Mol. Cell Biol., 2003, 4, 552-565.

49 R. B. Ravelli, B. Gigant, P. A. Curmi, I. Jourdain, S. Lachkar, A. Sobel and M. Knossow, Nature, 2004, 428, 198-202.

50 Schrödinger Suite 2015-1 Protein Preparation Wizard, Epik version 3.2, Schrödinger, LLC, New York, NY, 2015, Impact version 6.7, Schrödinger, LLC, New York, NY, 2015, Prime version 4.0, Schrödinger, LLC, New York, NY, 2015.

51 N. J. Halbrook and R. V. Lawrence, J. Org. Chem., 1966, 31, 4246-4247.

52 J. Yan, J. H. Hu, B. J. An, L. Huang and X. S. Li, Eur. J. Med. Chem., 2017, 125, 663-675.

53 F. C. Bernstein, T. F. Koetzle, G. J. Williams, E. E. Meyer Jr, M. D. Brice, J. R. Rodgers, O. Kennard, T. Shimanouchi and M. Tasumi, J. Mol. Biol., 1977, 11, 535-542. 